\title{
PERLINDUNGAN KONSUMEN TERHADAP PRODUK MAKANAN KADALUARSA DI KOTA BATAM
}

\author{
Rina Shahriyani Shahrullah*, Hindra** \\ Fakultas Hukum,Universitas Internasional Batam
}

\begin{abstract}
The purpose of this study is to analyze Law No. 8 of 1999 on Consumer Protection on Expired Food Products in Batam City. This research is classified as qualitative research with empirical/sociological legal res,earch. Hence, the data is collected from interviews, observation and literature study. The results of this study can be concluded as follows: the implementation of Law No. 8 of 1999 on Consumer Protection against expired food products in Batam has been well understood by business or shop owners. They have adopted a sense of absolute responsibility (strict liability). Therefore, when consumers complain regarding the expired goods, they have provided compensation in accordance with the agreement.
\end{abstract}

Keywords: Consumer protection, expired food, Batam City

\begin{abstract}
Abstrak
Tujuan penelitian ini adalah menganalisis pengaturan Undang-Undang Nomor 8 Tahun 1999 Tentang Perlindungan Konsumen Terhadap Produk Makanan Kadaluwarsa di Kota Batam. Penelitian ini tergolong penelitian kualitatif dengan jenis penelitian hukum empiris/sosiologis. Dengan demikian, data diperoleh dari wawacara, observasi dan studi kepustakaan. Hasil dari penelitian ini dapat ditarik kesimpulan berupa: pelaksanaan Undang-Undang Nomor 8 Tahun 1999 tentang Perlindungan Konsumen terhadap produk makanan kadaluarsa di Kota Batam telah dipahami dengan baik oleh pelaku usaha/pemilik toko. Mereka telah memiliki rasa tanggung jawab mutlak. Oleh karena itu, ketika konsumen mengajukan keluhan dalam hal barang kadaluwarsa, mereka telah memberikan ganti rugi sesuai dengan kesepakatan.
\end{abstract}

Kata Kunci: Perlindungan konsumen, makanan kadaluwarsa, Kota Batam

\footnotetext{
* Alamat Korespondensi : rina@uib.ac.id

** Alamat Korespondensi : hindra_mexindo@yahoo.com
} 


\section{A. Latar Belakang Masalah}

Hukum perlindungan konsumen dewasa ini mendapat cukup perhatian karena menyangkut aturan-aturan guna mensejahterakan masyarakat, bukan saja masyarakat dalam skala perorangan termasuk yang dilindungi masyarakat atas nama lembaga. Peranan hukum perlindungan konsumen dalam hal ini telah mengatur hak dan kewajiban baik konsumen maupun pelaku usaha. Melalui Undang-Undang Perlindungan Konsumen diupayakan agar masyarakat baik pelaku usaha maupun konsumen dalam kegiatan pemenuhan kehidupannya akan menjaga keseimbangan dalam pemenuhan hak dan kewajiban. Pemerintah melalui Undang-Undang ini berupaya mengatur, mengawasi, dan mengontrol, sehingga tercipta sistem yang kondusif saling berkaitan satu dengan yang lain. Dengan demikian tujuan mensejahterakan masyarakat luas dapat tercapai. ${ }^{1}$

Secara sistematis antara produsen dengan konsumen dalam suatu sistem distribusi dan pemasaran produk barang diupayakan tercapai produktivitas dan efektivitas usaha. Maka dalam hal ini diperlukan peran negara dalam melindungi kepentingan konsumen. Untuk itu perlu upaya pemerintah untuk melindungi konsumen dari produk yang merugikan dengan cara mengatur, mengawasi, serta mengendalikan produksi, distribusi, dan peredaran produk sehingga konsumen tidak dirugikan, baik kesehatannya maupun keuangannya. ${ }^{2}$ Perlindungan inilah yang diberi pemerintah melalui Hukum perlindungan konsumen menyangkut permasalahan mutu barang, cara prosedur produksi, syarat kesehatan, syarat pengemasan, syarat lingkungan dan sebagainya.

Tujuan hukum perlindungan konsumen adalah untuk meningkatkan martabat dan kesadaran konsumen. Secara tidak langsung, hukum ini juga akan mendorong produsen untuk melakukan usaha dengan penuh tanggung jawab. Namun, semua tujuan tersebut hanya dapat dicapai bila hukum perlindungan konsumen dapat diterapkan secara konsekuen. Untuk mewujudkan harapan tersebut, perlu dipenuhi beberapa persyaratan, antara lain: hukum perlindungan konsumen harus adil bagi konsumen maupun produsen jadi tidak hanya membebani produsen dengan tanggung jawab, tetapi juga melindungi hak-haknya untuk melakukan usaha dengan jujur; aparat pelaksana hukumnya harus dibekali dengan sarana yang memadai dan disertai dengan tanggung jawab; peningkatakan kesadaran konsumen akan hak-haknya; mengubah sistem nilai dalam masyarakat ke arah sikap tindak yang mendukung pelaksanaan perlindungan konsumen. ${ }^{3}$

Perlindungan yang diberikan tentu harus diikuti dengan adanya UndangUndang yang mengatur sehingga secara legalitas para pihak yang terkait dapat memahami mana kewajiban dan mana yang menjadi hak masing-masing. Sehingga hal ini juga menjadi acuan untuk mengarahkan kegiatan para pihak selama perjanjian dalam memenuhi alat kebutuhan dilakukan. Para pihak yang memahami akan adanya aturan Undang-Undang yang berlaku tentu akan merasakan kenyamanan dalam menjalankan transaksi, karena ketika terjadi permasalahan berkenaan tentang sengketa hak, maka mereka dapat meminta

\footnotetext{
${ }^{1}$ Celina Tri Siwi Kristiyanti, Hukum Perlindungan Konsumen, Jakarta: Sinar Grafika, 2014, h. 1

${ }^{2}$ Janus Sidabalok, Hukum Perlindungan Konsumen Di Indonesia, Bandung: PT Citra Aditya Bakti, 2010, h. 23-24

${ }^{3}$ Op.Cit, h. 10
} 
bantuan kepada pihak yang berwenang dengan mengembalikan permasalahan (sengketa) tersebut kepada aturan/norma-norma hukum yang berlaku.

Dalam menawarkan barangnya seorang pelaku usaha harus memberikan informasi yang benar termasuklah informasi tentang barang atau jasa tersebut sudah lewat waktu (kadaluwarsa). Jika pelaku usaha menyediakan barang atau jasa yang rusak, tercemar tanpa memberikan informasi yng benar, maka ia wajib menariknya dari peredaran. Berarti dalam hal ini terhadap barang-barang yang sudah lewat waktu penggunaan (kadaluwarsa), maka Undang-Undang memerintahkan pelaku usaha untuk menarik dari peredaran.

Hal ini juga diperkuat lagi dalam Pasal 9 ayat 1 butir $\mathrm{f}$ dan ayat 3 Undang-Undang Perlindungan Konsumen (UUPK) ini menyatakan bahwa melarang pelaku usaha untuk menawarkan, mempromosikan barang dan/atau jasa secara tidak benar seolah-olah barang atau jasa tersebut tidak mengandung cacat tersembunyi. Pasal 3 Undang-Undang Perlindungan Konsumen (UUPK) ini menyatakan bahwa pelaku usaha yang melakukan pelanggaran pada ayat 1 dilarang melanjutkan penawaran, promosi dan periklanan barang dan/atau jasa tersebut.

Berbicara pelaksanaan pertanggungjawaban pelaku usaha terhadap konsumen dalam mendapatkan produk makanan kadaluwarsa yang diperjualbelikan pelaku usaha (toko) khususnya di Kota Batam tidak jarang terjadi. Melihat kepada realita yang terjadi konsumen sangat dirugikan dengan tindakan pelaku usaha, sehingga mereka meminta pertanggungjawaban sebagaimana telah diatur oleh Undang-Undang perlindungan konsumen. Untuk mewujudkan tanggungjawab tersebut, maka diperlukan faktor-faktor yang dapat mempengaruhi hukum itu berfungsi dalam masyarakat diantaranya meliputi kaedah hukum/peraturan itu sendiri; petugas/penegak hukum; sarana atau fasilitas yang digunakan oleh penegak hukum; dan kesadaran masyarakat. ${ }^{4}$

Pertanggungjawaban pelaku usaha terhadap produk makanan kadaluwarsa, termasuk kepada permasalahan yang muncul setelah dilakukannya akad jual beli. Sehingga bahasan ini dapat digolongkan kepada layanan purnajual, terutama mencakup permasalahan kepastian atas: ganti rugi jika barang/jasa yang diberikan tidak sesuai dengan perjanjian semula; barang yang digunakan jika mengalami kerusakan tertentu dapat diperbaiki secara cuma-cuma selama jangka waktu garansi; dan suku cadang selalu tersedia dalam jumlah cukup dan tersebar luas dalam jangka waktu yang relatif lama setelah transaksi konsumen dilakukan. ${ }^{5}$

Menurut Undang-Undang Perlindungan Konsumen (UUPK) dijelaskan bahwa kerugian yang dirasakan oleh pihak konsumen, perlu dilakukan adanya kewajiban bagi pelaku usaha untuk membayar ganti rugi sebagai wujud adanya layanan purnajual. Sehingga dengan demikian pertanggungjawaban yang sering terjadi di lapangan, yang mengakibatkan konsumen dirugikan oleh pelaku usaha dapat diatasi sesuai dengan Undang-Undang Hukum Perlindungan Konsumen yang berlaku.

${ }^{4}$ Zainuddin Ali, Sosiologi Hukum, Jakarta: Sinar Grafika, 2014, 62

${ }^{5}$ Celina Tri Siwi Kristiyanti, Op.Cit., h. 150 


\section{B. Rumusan Masalah}

Rumusan permasalahan dalam penelitian ini meliputi beberapa kajian diantaranya :

1. Bagaimana pengaturan Undang-Undang Nomor 8 Tahun 1999 Tentang Perlindungan Konsumen Terhadap Produk Makanan Kadaluwarsa di Kota Batam?

2. Bagaimana penerapan dampak Undang-Undang Nomor 8 Tahun 1999 Tentang Perlindungan Konsumen Terhadap Produk Makanan Kadaluwarsa di Kota Batam?

3. Bagaimana solusi dari Undang-Undang Nomor 8 Tahun 1999 terhadap dampak negatif penggunaan produk Makanan Kadaluwarsa di Kota Batam?

\section{Metode Penelitian}

Rancangan yang digunakan dalam penelitian ini dengan menggunakan suatu panduan pedoman untuk mengumpulkan data, ${ }^{6}$ mengolah data, ${ }^{7}$ menganalisa serta mengkonstruksikannya. Penelitian ini tergolong penelitian empiris/sosiologis (hukum sosiologis). ${ }^{8}$ Penelitian hukum empiris merupakan istilah lain yang digunakan dalam penelitian hukum sosilogis, dan dapat disebut juga dengan penelitian lapangan. Jenis penelitian sosiologis yang Penulis lakukan adalah berbentuk jenis penelitian penerapan. Jika penelitian hukum normatif didasarkan pada data sekunder, maka penelitian hukum sosiologis bertitik tolak pada data primer. Data primernya berkenaan tentang informasi yang diperoleh langsung dari lapangan melalui pengamatan (observasi), wawancara atau penyebaran kueisioner. ${ }^{9}$

Penelitian ini berbentuk penelitian hukum sosiologis. Dalam konsep ini hukum dikonsepkan sebagai pranata sosial yang secara riil dikaitkan dengan variabel-variabel sosial yang ada. ${ }^{10}$ Sifat penelitian yang dilakukan adalah bentuk penelitian deskriptif artinya Penulis bermaksud memberikan gambaran yang jelas secara sistematis, ${ }^{11}$ terhadap permasalahan yang berkenaan tentang penerapan Undang-Undang Nomor 8 Tahun 1999 tentang Perlindungan Konsumen Terhadap Produk Makanan Kadaluwarsa di Kota Batam.

Dalam penelitian ini Penulis mencoba menganalisa tentang penerapan hukum perlindungan konsumen pada beberapa (pengusaha)/toko yang menjual beberapa produk makanan yang kadaluwarsa kepada masyarakat, kemudian dilakukan analisis menurut Undang-Undang Perlindungan Konsumen tersebut. Terdapat beberapa langkah yang dapat disusun dalam rancangan perencanaan penelitian sebagai berikut: Perumusan Masalah; Penyusunan kerangka teoritis dan konsepsionil; Tipe perencanaan perencanaan penelitian atau rencana pemeriksaan; Tata cara

\footnotetext{
${ }^{6}$ Kegiatan untuk mencatat: suatu kejadian/peristiwa atau mencatat karakteristik elemen atau mencatat nilai variabel disebut mengumpulkan data. Lihat Supranto dan Nandan Limakrisna, Petunjuk Praktis Penelitian Ilmiah Untuk Menyusun Skripsi, Penelitian, dan Disertasi, Jakarta: Mitra Wacana Media, 2012, h. 57

${ }^{7}$ Adapun yang dimaksud dengan mengolah data ialah kegiatan untuk mendapatkan data ringkasan berbentuk angka berdasarkan data mentah dengan menggunakan rumus tertentu, misalnya menghitung jumlah total, rata-rata, persenrase dan berbagai nilai koefisien variasi, koefisien korelasi, koefisien determinasi dan koefisien regresi. Lihat Ibiden.,

${ }^{8}$ Zainuddin Ali, Op.Cit., h. 105

${ }^{9}$ Suratman, dan Philips Dillah, Metode Penelitian Hukum, Bandung: Alfabeta, 2014, h. 53

${ }^{10}$ ZainuddinAli, 2006, Sosiologi Hukum, Jakarta: Sinar Grafika, 2006, hl. 13.

${ }^{11}$ Bambang Waluyo, Penelitian Hukum, Op.cit., hl. 8-9.
} 
menentukan ruang lingkup bahan pustaka dan/atau responden; Metode pengumpulan data meliputi alat-alat pengumpulan data, jangka waktu penelitian dan cara-cara yang ditempuh apabila menemui kesulitan dalam penelitian; dan Pedoman kerja biasanya mencakup tugas dan dari personalia penelitian. ${ }^{12}$

Sedangkan rangkaian kerja yang dipakai dalam hal ini adalah berupa study literatur untuk mengenal latar belakang masalah, menelaah landasan konsep/Teori dan aspek yuridis. Sebagai tahapan inti penelitian induktif dilakukan penggalian data lapangan melalui teknik wawancara mendalam kepada para pelaku usaha yang menerapkan Undang-Undang Perlindungan Konsumen, terutama dalam hal melakukan penjualan barang-barang produk makanan yang kadaluwarsa.

Objek penelitian dalam penelitian ini adalah masyarakat yang dijadikan sebagai responden yang akan dijadikan sebagai sumber informasi adalah berkenaan tentang penerapan Undang-Undang Perlindungan Konsumen melindungi hak konsumen yang dirugikan akibat membeli makanan yang kualitas nya sudah tidak layak konsumsi lagi (kadaluwarsa). Penelitian ini tergolong penelitian hukum sosiologis memiliki data primer dan sekunder. Data primer diperoleh dari hasil wawancara dan observasi sedangkan data sekunder diperoleh dari bahan-bahan hukum primer dan sekunder ${ }^{13}$. Data primer dalam penelitian ini diperoleh dengan wawancara dan observasi. Data primer atau data tangan pertama merupakan data yang diperoleh secara langsung dari subjek penelitian dengan mengenakan alat pengukuran atau alat pengambilan data langsung pada subjek sebagai sumber informasi yang dicari. ${ }^{14}$ Adapun responden dalam penelitian ini adalah perwakilan penjual toko, minimarket, dan supermarket yang menjual produk makanan yang ada di Kota Batam. Data Sekunder, merupakan data yang diperoleh dari tangan kedua atau informasi yang diperoleh dari pihak lain, tidak langsung diperoleh oleh Peneliti dari subjek penelitian nya. Data sekunder berwujud data dokumentasi atau data laporan yang telah tersedia. ${ }^{15}$

Data sekunder yang digunakan dalam karya tulis ini terdiri dari :

Pertama, Bahan Hukum Primer adalah bahan hukum yang mempunyai otoritas

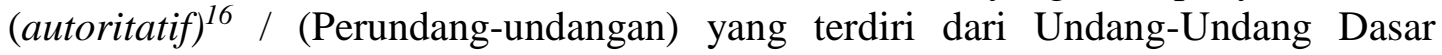
Republik Indonesia 1945, Kitab Undang-Undang Hukum Perdata, Undang-Undang Nomor 8 Tahun 1999 Tentang Perlindungan Konsumen, dan lain peraturan yang terkait dengan penelitian ini;

Kedua, Bahan Hukum Sekunder adalah semua publikasi tentang hukum yang merupakan dokumen yang tidak resmi. ${ }^{17}$ Bahan hukum sekunder, memberikan penjelasan mengenai bahan hukum primer, seperti misalnya Rancangan UndangUndang, hasil-hasil penelitian, buku-buku, hasil karya dari kalangan hukum, dan seterusnya. ${ }^{18}$;

Ketiga, Bahan Hukum Tersier, yakni bahan yang memberikan petunjuk maupun penjelasan terhadap bahan hukum primer dan sekunder seperti kamus, ensiklopedia, indeks kumulatif dan seterusnya. ${ }^{19}$

\footnotetext{
${ }^{12}$ Soerjono Soekanto, Pengantar Penelitian Hukum, Jakarta: UI-Press, 2008, h. 64

${ }^{13}$ Soerjono Soekanto, Pengantar Penelitian Hukum, Jakarta: Rajawali Pers, 1996, h. 52

${ }^{14}$ Syaifuddin Azwar, Metode Penelitian, Yogyakarta: Pustaka Pelajar, 2012, h. 91

${ }^{15}$ Ibiden.,

${ }^{16}$ Zainuddin Ali, Op.Cit., h. 47

${ }^{17}$ Ibid., h. 54

${ }^{18} \mathrm{Ibid}$, hal 52

${ }^{19}$ Soerjono Soekanto, Op.Cit., h. 52
} 
Teknik pengumpulan data dalam penelitian ini meliputi studi dokumen atau bahan pustaka, pengamatan atau observasi, dan wawancara atau interview. ${ }^{20}$ Ketiga teknik atau alat penelitian tersebut dipergunakan secara bersama-sama dalam penelitian ini. Menggunakan data sekunder sebagai data awalnya, kemudian dilanjutkan dengan data primer atau data lapangan. ${ }^{21}$

Adapun teknik pengumpulan data primer dalam penelitian ini adalah melalui: Pertama, Observasi Alamiah/Naturalistic Observation (pengamatan langsung), di mana dalam pendekatan alamiah dengan adanya campur tangan sama sekali dari pihak Peneliti. Objek observasi adalah fenomena-fenomena yang dibicarakan terjadi secara alamiah.

Kedua, Wawancara (teknik pengumpulan data dengan jalan mengadakan komunikasi secara lisan dengan sumber data) dengan harapan Peneliti dapat mengungkapkan berbagai aspek dari masyarakat maupun dari individu yang menjadi bagian masyarakat. $^{22}$

Ketiga, studi kepustakaan (library research). ${ }^{23}$

Analisis data pada penelitian hukum sosiologis ini adalah analisis data kualitatif. Adapun tahapan yang ditempuh dalam analisis data adalah sebagai berikut: mengumpulkan hasil data primer dan data sekunder; membandingkan antara data primer (hasil wawancara dan observasi) dengan data sekunder (landasan konsepsional dan landasan teori); membuat ringkasan dari hasil perbandingan data primer dan sekunder; melakukan analisis data dan pengambilan kesimpulan.

\section{Hasil Penelitian dan Pembahasan}

\section{Pengaturan Undang-Undang Nomor 8 Tahun 1999 Tentang Perlindungan Konsumen Terhadap Produk Makanan Kadaluwarsa di Kota Batam.}

Menurut Kamus Besar Bahasa Indonesia (KBBI) menjelaskan perlindungan merupakan tempat berlindung; dan perbuatan (hal dan sebagainya) melindungi. ${ }^{24}$ Pengertian perlindungan hukum adalah suatu perlindungan yang diberikan terhadap subyek hukum dalam bentuk perangkat hukum baik yang bersifat preventif maupun yang bersifat represif, baik yang tertulis maupun tidak tertulis. Dengan kata lain perlindungan hukum sebagai suatu gambaran dari fungsi hukum, yaitu konsep dimana hukum dapat memberikan suatu keadilan, ketertiban, kepastian, kemanfaatan dan kedamaian. ${ }^{25}$ Menurut Pasal 1 ayat (1) Undang-Undang Nomor 8 Tahun 1999 menjelaskan bahwa yang dimaksud dengan perlindungan konsumen adalah segala upaya yang menjamin adanya kepastian hukum untuk memberi kepada konsumen.

Istilah konsumen berasal dari bahasa consumer (Inggris-Amerika), atau consument/konsumen (Belanda). Pengertian dari consumer atau consument itu tergantung dalam posisi di mana ia berada. Secara harfiah arti kata consumer adalah

\footnotetext{
${ }^{20}$ Soerjono Soekanto, op.cit., h. 21

${ }^{21}$ Zainal dan Amiruddin Asikin, Pengantar Metode Penelitian Hukum, Jakarta: Raja Grafindo Persada, 2004, hal. 133.

${ }^{22}$ Soerjono Soekanto, Op.Cit., h. 227

${ }^{23}$ Soerjono Soekanto, Op.Cit., hal. 12.

${ }^{24}$ Departemen Pendidikan Nasional, Kamus Besar Bahasa Indonesia Jakarta: Balai Pustaka, 2005, h. 674.

${ }^{25}$ Polewali Mandar, 2014, "Status Hukum", Serial Blog, URL: http://statushukum. com/ tentangstatus-hukum Diakses 29 Juli 2016
} 
(lawan dari produsen) setiap orang yang menggunakan barang. ${ }^{26}$ Tujuan penggunaan barang dan jasa itu nanti menentukan termasuk konsumen kelompok mana pengguna tersbut. Begitu pula Kamus Bahasa Inggris-Indonesia memberi arti kata consumer sebagai pemakai atau konsumen. Selanjutnya istilah konsumen digunakan dalam buku ini, oleh karena istilah ini telah memasyarakat di Indonesia, seperti istilah consumer dalam masyarakat internasional. ${ }^{27}$

Konsumen umumnya diartikan sebagai pemakai terakhir dari produk yang diserahkan kepada meraka oleh pengusaha, yaitu setiap orang yang mendapatkan barang untuk dipakai dan tidak untuk diperdagangkan atau diperjualbelikan. ${ }^{28}$ Menurut Az. Nasution menegaskan bahwa ada beberapa batasan tentang konsumen, yaitu: ${ }^{29}$

Pertama, konsumen umum adalah setiap orang yang mendapatkan barang atau jasa digunakan untuk tujuan tertentu.

Kedua, konsumen antara adalah setiap orang yang mendapatkan barang dan/jasa untuk digunakan dengan tujuan membuat barang/jasa lain atau untuk diperdagangkan dengan tujuan komersial.

Ketiga, konsumen akhir adalah setiap orang alami yang mendapat dan menggunakan barang dan/atau jasa untuk tujuan memenuhi kebutuhan hidupnya pribadi, keluarga dan atau rumah tangga dan tidak untuk diperdagangkan kembali (nonkomersial).

Dalam bukunya, Pengantar Hukum Bisnis, Munir Fuady mengemukakan bahwa konsumen adalah pengguna akhir (end user) dari suatu produk, yaitu setiap pemakai barang dan/atau jasa yang tersedia dalam masyarakat, baik bagi kepentingan diri sendiri, keluarga, orang lain, maupun makhluk hidup lain, dan tidak untuk diperdagangkan.

Istilah produsen berasal dari bahasa Belanda yakni producent, dalam bahasa Inggris, producer yang artinya adalah penghasil. Produsen sering diartikan sebagai pengusaha yang menghasilkan barang dan jasa. Dalam pengertian ini termasuk di dalamnya pembuat, grosir, leveransir, dan pengencer profesional, yaitu setiap orang/badan yang ikut serta dalam penyediaan barang dan jasa hingga sampai ke tangan konsumen. ${ }^{30}$ Dengan demikian, produsen tidak hanya diartikan sebagai pihak pembuat/pabrik yang menghasilkan produk saja, tetapi juga mereka yang terkait dengan penyampaian/peredaran produk hingga sampai ke tangan konsumen.

Pasal 1 ayat (3) Undang-Undang Nomor 8 Tahun 1999 menjelaskan, bahwa yang dimaksud dengan Pelaku usaha adalah setiap orang perseorangan atau badan usaha, baik yang berbentuk badan hukum maupun bukan badan hukum yang didirikan dan berkedudukan atau melakukan kegiatan dalam wilayah hukum negara Republik Indonesia, baik sendiri maupun bersama-sama melalui perjanjian menyelenggarakan kegiatan usaha dalam berbagai bidang ekonomi. Berdasarkan doktrin dan yurisprudensi yang berkembang mengartikan konsumen sebagai "the person who obtains goods or services for personal or family purposes". Dari definisi

\footnotetext{
${ }^{26}$ Az. Nasution. Hukum Perlindungan Konsumen, Jakarta: Diadit Media. 2011, h. 21

27 Ibid. , hal. 21

${ }^{28}$ Janus Sidabalok. Hukum Perlindungan Konsumen di Indonesia. Bandung: PT. Citra Aditya Bakti, 2010. Cet. II, h. 17

${ }^{29}$ Celina Tri Siwi Kristiyanti. Hukum Perlindungan Konsumen, Jakarta: Sinar Grafika, 2014, h. 25

${ }^{30}$ Janus Sidabalok. Hukum Perlindungan Konsumen di Indonesia. Bandung: PT. Citra Aditya Bakti, 2010. Cet. II, h. 16
} 
di atas terkandung dua unsur, yaitu (1) konsumen hanya orang dan (2) barang atau jasa yang digunakan untuk keperluan pribadi atau keluarganya. ${ }^{31}$

Perlindungan konsumen merupakan bagian dari hukum konsumen, hal ini dapat kita lihat bahwa hukum konsumen memiliki skala yang lebih luas karena hukum konsumen meliputi berbagai aspek hukum yang didalamnya terdapat kepentingan pihak konsumen dan salah satu bagian dari hukum konsumen ini adalah aspek perlindungannya, misalnya bagaimana cara mempertahankan hak-hak konsumen terhadap gangguan pihak lain. ${ }^{32}$

Suatu perkembangan dalam masyarakat dewasa ini, khususnya di negaranegara maju, adalah semakin meningkatnya perhatian terhadap masalah perlindungan konsumen. Apabila dimasa-masa yang lalu pihak produsen dan industri-industri yang dipandang sangat berjasa bagi perkembangan perekonomian negara mendapat perhatian lebih besar, maka perlindungan terhadap konsumen lebih mendapat perhatian, sesuai dengan meningkatnya perlindungan terhadap hak-hak asasi manusia. Pihak konsumen yang dipandang lebih lemah hukum perlu mendapat perlindungan lebih besar dibanding masa-masa yang lalu. Maka dari itu untuk melindungi hak-hak konsumen maka dibuatlah Undang-Undang tentang perlindungan konsume ${ }^{33}$

Undang-undang memberikan hak-hak tertentu kepada konsumen yang apabila hak tersebut dilanggar, berpotensi untuk terjadinya kejahatan terhadap konsumen. Seperti yang diatur dalam Undang-Undang perlindungan konsumen tentang perbuatan yang dilarang bagi pelaku usaha yakni pelaku usaha mempromosi dan/atau memperdagangkan barang dan/atau jasa yang tidak memenuhi atau tidak sesuai dengan standar yang dipersyaratkan dan ditentukan dalam ketentuan Peraturan Perundang-undangan. ${ }^{34}$

Sebelum Undang-Undang Perlindungan Konsumen diberlakukan, beberapa perbuatan yang merugikan konsumen belum dinyatakan sebagai perbuatan pidana. Tetapi dengan berkembangnya dunia industrial dan perdagangan melahirkan dampak kerugian publik. Pemerintah kemudian mengantisipasi masalah itu dan kemudian memformulasikannya dalam bentuk hukum pidana. Inilah yang disebut dengan kriminalisasi perlindungan konsumen. ${ }^{35}$

Berbagai peraturan yang mengatur ketentuan pidana untuk melindungi konsumen sudah banyak yang diberlakukan sebelum diundangkannya UndangUndang Perlindungan Konsumen (UUPK) meskipun belum terpadu dan komprehensif. ${ }^{36}$ Misalnya dalam Kitab Undang-Undang Hukum Perdata, di dalam Peraturan Perundang-undangan, mengenai kesehatan, pangan, perdagangan, perumahan dan sebagainya, maka peraturan hukum pidana perlindungan konsumen dapat diklasifikasikan kedalam tiga kelompok produk legislatif, yakni: Kitab Undang-Undang Hukum Perdata (KUHP); Undang Perlindungan Konsumen

\footnotetext{
${ }^{31}$ Shidarta, 2006, Hukum Perlindungan Konsumen Indonesia edisi Revisi 2006, Jakarta: Gramedia Widiasarana Indonesia, h. 3

${ }^{32}$ Ibid. , h. 12

${ }^{33}$ Erman Rajagukguk Dkk. Hukum Perlindungan Konsumen. Bandung: Mandarmaju. 2000, h. 43

${ }^{34}$ Artikel yang berjudul "Kejahatan Konsumen" di akses pada www. elisaturatmi. wordpress. com pada tanggal 2 Agustus 2016 pada pukul 10. 00

${ }^{35}$ N. H. T. siahaan. Hukum Konsumen "Perlinungan Konsumen Dan Tanggung Jawab Produsen”. Jakarta: Panta Rai. 2005, h. 177

${ }^{36}$ Ibid, h. 178
} 
(UUPK); dan Peraturan Perundang-undangan di luar Undang Perlindungan Konsumen (UUPK) dan Kitab Undang-Undang Hukum Perdata (KUHP). ${ }^{37}$

Jadi yang dimaksud dengan kata perlindungan, yaitu suatu tindakan perlindungan atau tindakan melindungi dari pihak-pihak tertentu yang ditujukan untuk pihak tertentu dengan menggunakan cara-cara tertentu. Perlindungan hukum merupakan bentuk perlindungan yang utama karena berdasarkan pemikiran bahwa hukum sebagai sarana yang dapat mengakomodisi kepentingan dan hak konsumen secara komprehensif, di samping itu hukum memiliki kekuatan memaksa yang diakui secara resmi di dalam negara, sehingga dapat dilaksanakan secara permanen. Berbeda dengan perlindungan melalui institusi lainnya seperti perlindungan melalui institusi lainnya perlindungan ekonomi atau politik misalnya, yang bersifat temporer atau sementara.

Perlindungan hukum dapat diartikan sebagai perlindungan oleh hukum atau perlindungan dengan menggunakan pranata dan sarana hukum. Hukum dalam memberikan perlindungan dapat melaui cara-cara tertentu, antara lain dengan membuat peraturan (by giving regulation), bertujuan untuk menjamin hak dan kewajiban; menjamin hak-hak para subyek hukum. Menegakkan peraturan (by law enforcement) melalui hukum administrasi negara yang berfungsi untuk mencegah (preventive) terjadinya pelanggaran hak-hak konsumen, dengan perijinan dan pengawasan; hukum pidana yang berfungsi untuk menanggulangi (repressive) pelanggaran Undang Perlindungan Konsumen (UUPK), dengan mengenakan sanksi pidana dan hukuman; hukum perdata yang berfungsi memulihkan hak (curative; recovery;remedy), dengan membayar kompensasi atau ganti kerugian. ${ }^{38}$

Hukum perlindungan konsumen yang berlaku di Indonesia memiliki dasar hukum yang telah ditetapkan oleh pemerintah. Dengan adanya dasar hukum yang pasti, perlindungan terhadap hak-hak konsumen bisa dilakukan dengan penuh optimisme. Pengaturan tentang hukum perlindungan konsumen telah diatur dalam Undang Perlindungan Konsumen (UUPK) Nomor 8 Tahun 1999. Berdasarkan Pasal 1 angka (1) Undang Perlindungan Konsumen (UUPK) disebutkan bahwa Perlindungan konsumen adalah segala upaya yang menjamin adanya kepastian hukum untuk memberi perlindungan kepada konsumen. Kepastian hukum untuk memberi perlindungan kepada konsumen berupa perlindungan terhadap hak-hak konsumen, yang diperkuat melalui undang-undang khusus, memberi harapan agar pelaku usaha tidak bertindak sewenang-wenang yang selalu merugikan hak-hak konsumen. ${ }^{39}$

Menurut Gandi dalam buku Janus Sidabalok mendefinsikan, bahwa yang dimaksud dengan standarisasi adalah proses penyusunan dan penerapan aturanaturan dalam pendekatan secara teratur bagi kegiatan tertentu untuk kemanfaatan dan dengan kerjasama dari semua pihak yang berkepentingan, khususnya untuk meningkatkan penghematan menyeluruh secara optimum dengan memperhatikan kondisi fungsional dan persyaratan keamanan. Hal ini didasarkan pada konsolidasi dari hasil (ilmu) teknologi dan pengalaman. ${ }^{40}$

\footnotetext{
${ }^{37}$ Ibid, h. 178

${ }^{38}$ Wahyu Sasongko, Ketentuan-Ketentuan Pokok Hukum Perlindungan Konsumen Bandar Lampung: Universitas Lampung. 2007, h 31.

${ }^{39}$ Abdul Halim Barkatulah. Hukum Perlindungan Konsumen Kajian Teoretis dan Perkembangan Pemikiran, Bandung: Nusa Media. 2008, h. 15

${ }^{40}$ Gandi, 1980. Perlindungan Konsumen dilihat dari Sudut Pengaturan Standarisasi Hasil Industri, makalah pada Simposium Aspek-aspek Hukum Perlindungan Konsumen, BPHN-Binacipta, Jakarta, h.
} 
Selanjutnya Gandi dalam buku Janus Sidabalok, mengatakan bahwa dengan standarisasi akan diperoleh manfaat. Adapun manfaat dari standarisasi adalah pemakaian bahan secara ekonomi, perbaikan mutu, penurunan ongkos produksi, dan penyerahan yang cepat; penyerderhanaan pengiriman dan penanganan barang; perdagangan yang adil, peningkatan kepuasan langganan; interchangeability komponen memunkinan subcontracting; dan keselamatan kehidupan dan harta. ${ }^{41}$

Dalam mencapai tujuan suatu standarisasi, yang perlu diperhatikan dalam standar produk adalah: ${ }^{42}$ terminologi dan definisi yang dapat dipakai sebagai bahasa yang sama-sama dimengerti oleh produsen, penjual, distributor, dan konsumen; perlu ditingkatkan minimal bagi keselamatan, yang ditetapkan secara ahli, yang memperhitungkan resiko yang dapat terima; perlu ditetapkan cara dan produsen untuk menentukan apakah memenuhi persyaratan keselamatan minimum; perlu diusahakan kemungkinan dipertukarkan, baik bagi produk secara keseluruhan maupun bagi komponennya; perlu ditetapkan kategori atau deret ukur yang cocok bagi konsumen dan juga kemungkinan produsen untuk menghilangkan ragam produk yang tidak perlu; dan perlu dikembangkan seperangkat cara dan prosedur yang lengkap bagi pengukuran kemampuan dan mutu.

Secara geografis Kota Batam mempunyai posisi yang strategis karena berada pada jalur pelayaran Internasional dan hanya berjarak 12,5 mil laut dengan negara Singapura. Luas wilayah Kota Batam 426.563 Ha, terdiri dari 318.298 Ha luas laut dan 108.265 Ha luas darat Terdiri lebih dari 370 buah pulau, di mana beberapa diantaranya merupakan pulau kecil dan terdepan yang berbatasan dengan Negara Singapura dan Malaysia.

Berdasarkan geografis Kota Batam di atas diketahui bahwa kota Batam berada pada posisi silang, yang berdekatan dengan negara lain. Hal ini tentu akan berpengaruh kepada mudahnya proses ekspor dan impor yang akan terjadi antar beberapa negara tersebut dengan menjadikan Batam sebagai daerah persinggahan. Hal demikian juga akan berpengaruh kepada peredaran barang dan jasa yang terjadi di Kota Batam, terutam dalam hal produk makanan.

Istilah daluwarsa (verjaring) adalah suatu alat untuk memperoleh sesuatu atau membebaskan dari suatu perikatan dengan lewatnya suatu waktu tertentu dan atas syarat-syarat yang ditentukan. ${ }^{43}$ Kedaluwarsa atau lewat waktu juga dapat mengakibatkan hapusnya kontrak antara para pihak, hal ini diatur dalam Pasal 1967 Kitab Undang-Undang Hukum Perdata. Berdasarkan pengertian daluwarsa menurut Kitab Undang-Undang Hukum Perdata di atas, maka daluwarsa dapat dibagi menjadi dua macam yaitu :

Pertama, Ecquisitiever verjaring, adalah lampu waktu yang menimbulkan hak, syarat adanya kedaluwarsa ini harus ada itikad baik dari pihak yang menguasai benda tersebut; dan

Kedua, Extinctieve verjaring, adalah lampu waktu yang melenyapkan atau membebaskan terhadap tagihan atau kewajiban. ${ }^{44}$ Menurut Salim HS,

80 dalam buku Janus Sidabalok. Hukum Perlindungan Konsumen di Indonesia. Bandung: PT. Citra Aditya Bakti, 2010. Cet. II, h. 19

${ }^{41}$ Ibid, h. 20

${ }^{42}$ Ibid, h. 20

${ }^{43}$ Salim HS, Op. Cit. , h. 201

${ }^{44}$ Salim HS, Op. Cit. , h. 202 
mendefinisikan bahwa ada beberapa tujuan dibuatnya lembaga kedaluwarsa yaitu: melindungi kepentingan masyarakat; dan melindungi si berutang dengan jalan mengamankannya terhadap tuntutan yang sudah kuno. ${ }^{45}$

Dalam mendapatkan produk makanan tentunya tidak sedikit bentuk kecurangan yang dilakukan oleh pihak pelaku usaha dalam rangka menghadirkan produk tersebut sampai ke tangan konsumen. Mulai dari pengolahan produk, berapa banyak kecurangan yang dilakukan berupa menambahkan beberapa zat berbahaya ke dalam produk, dalam promosi berapa banyak informasi produk yang tidak sesuai dengan ketentuan yang sebenarnya, begitu juga dalam hal mutu dan kualitas barang tersebut. Untuk melindungi hak konsumen dari tindakan kecurangan yang dilakukan pihak pelaku usaha, maka diperlukan Hukum Perlindungan Konsumen. Adapun yang dimaksud dengan produk sebagaimana yang diatur dalam Undang-Undang Perlindungan Konsumen sebagaimana diatur dalam Pasal 1 ayat 4 yang menyatakan bahwa "Barang adalah setiap benda baik berwujud atau tidak berwujud maupun tidak dapat dihabiskan, yang dapat untuk diperdagangkan, dipakai, dipergunakan, atau dimanfaatkan oleh konsumen".

Berdasarkan Pasal tersebut diketahui bahwa produk merupakan sejenis barang yang dapat diperjualbelikan dalam perdagangan, dapat dipakai, dapat dimanfaatkan oleh pihak konsumen. Termasuklah dalam hal ini makanan merupakan produk atau barang yang dapat dimanfaatkan oleh pihak konsumen. Dengan adanya produk makanan, maka konsumen dapat mempergunakan produk tersebut untuk mempertahankan hidup, memenuhi kebutuhan pokok dan mendapatkan kekenyangan setelah menikmati produk makanan tersebut. Tentunya untuk mencapai hal demikian tidaklah mudah. Karena setiap produk makanan yang layak untuk dikonsumsi tentunya harus memmenuhi kriteria yang memberikan dampak positif bagi pemakainya, misalnya saja dengan memakan makanan tersebut menjadikan konsumen lebih kenyang, terjamin kesehatannya dan mendapatkan keselamatan.

Hal ini sebagaimana terdapat dalam Pasal 4 yang menyatakan bahwa Hak konsumen adalah: Hak atas kenyamanan, keamanan, dan keselamatan dalam mengkonsumsi barang dan/atau jasa; Hak untuk memilih barang dan/atau jasa serta mendapatkan barang dan/atau jasa tersebut sesuai dengan nilai tukar dan kondisi serta jaminan yang dijanjikan; Hak atas informasi yang benar, jelas, dan jujur mengenai kondisi dan jaminan barang dan/atau jasa; dan hak untuk didengar pendapat dan keluhannya atas barang dan/atau jasa yang digunakan.

Di samping itu dalam Pasal 6 telah diatur bahwa hak pelaku usaha meliputi hak untuk menerima pembayaran yang sesuai dengan kesepakatan mengenai kondisi dan nilai tukar barang dan/atau jasa yang diperdagangkan; hak untuk mendapat perlindungan hukum dari tindakan konsumen yang beritikad tidak baik; hak untuk melakukan pembelaan diri sepatunya di dalam penyelesaian hukum sengketa konsumen; hak untuk rehabilitasi nama baik apabila terbukti secara hukum bahwa kerugian konsumen tidak diakibatkan oleh barang dan/atau jasa yang diperdagangkan; dan hak-hak yang diatur dalam ketentuan peraturan perundangundangan lainnya.

Berdasarkan ketentuan lain sebagaimana diatur dalam Pasal 7 telah diatur mengenai kewajiban pelaku usaha adalah meliputi beritikad baik dalam melakukan kegiatan usahanya; memberikan informasi yang benar, jelas dan jujur mengenai kondisi dan jaminan barang dan/atau jasa serta memberi penjelasan penggunaan,

${ }^{45}$ Salim HS, Op. Cit. , h. 202 
perbaikan dan pemeliharaan; memperlakukan atau melayani konsumen secara benar dan jujur serta tidak diskriminatif; menjamin mutu barang dan/atau jasa yang diproduksi dan/atau diperdagangkan berdasarkan ketentuan standar mutu barang dan/atau jasa yang berlaku; memberi kesempatan kepada konsumen untuk menguji, dan/atau mencoba barang dan/atau jasa tertentu serta memberi jaminan dan/atau garansi atas barang yang dibuat dan/atau yang diperdagangkan; memberi kompensasi, ganti rugi dan/atau penggantian atas kerugian akibat penggunaan, pemakaian dan pemanfaatan barang dan/atau jasa yang diperdagangkan; dan memberi kompensasi, ganti rugi dan/atau penggantian apabila barang dan/atau jasa yang diterima atau dimanfaatkan tidak sesuai dengan perjanjian.

Berdasarkan ketentuan Undang-Undang Perlindungan Konsumen Pasal 8 ayat 1 huruf (g) menyebutkan bahwa "pelaku usaha dilarang untuk tidak mencantumkan tanggal kadaluwarsa atau jangka waktu penggunaan/ pemanfaatan yang paling baik atas barang tertentu". Berdasarkan pasal tersebut bahwa ketentuan jangka waktu penggunaan/ pemanfaatannya yang paling baik adalah terjemahan dari kata best before yang biasa digunakan dalam label produk makanan. Defenisi ini sama pemahamannya dengan istilah best before, karena kedua ketentuan waktu ini menyatakan perihal ketentuan baik untuk digunakan sebelum dan expiry date menyatakan tidak boleh digunakan arti kata sudah kadaluwarsa. Pada ayat dua Undang-Undang ini juga disebutkan bahwa barang yang dimaksud dalam ayat 1 termasuk hurug g adalah barang yang tidak membahayakan konsumen dan sesuai dengan ketentuan perundang-undangan berlaku, termasuklah dalam hal ini persediaan farmasi/pengobatan dan pangan tidak membahayakan konsumen menurut peraturan perundang-undangan yang berlaku. Sedangkan ayat 4 (empat) dalam Undang-Undang ini dinyatakan bahwa Menteri dan Menteri Teknis berwenang menarik barang dan/atau jasa dari peredaran.

Jadi pada intinya pasal ini tertuju pada dua hal yaitu larangan memproduksi barang dan/ atau jasa, dan larangan memperdagangkan barang atau jasa dimaksud. Larangan yang dimaksud menurut Nurmadjito dalam buku Ahmadi Miru menyatakan bahwa untuk mengupayakan agar barang atau jasa yang beredar di masyarakat merupakan produk yang layak edar, antara lain asal-usul, kualitas sesuai dengan informasi pengusaha baik melalui label, etiket, iklan dan lain sebagainya. ${ }^{46}$

Untuk memperoleh makanan yang berkualitas bagus dan tidak kadaluwarsa, maka perlu dilakukan beberapa upaya. Upaya-upaya yang dilakukan untuk menanggulangi peredaran makanan kadaluwarsa di masyarakat yakni upaya preventif dan upaya represif. Upaya preventif adalah upaya yang dilakukan sebelum terjadinya tindak pidana atau sebagai upaya pencegahan dari suatu tindak pidana. sedangkan upaya represif adalah upaya yang dilakukan setelah terjadinya tindak pidana tersebut terjadi dengan menindak lanjuti laporan-laporan yang muncul dari masyarakat.

Berdasarkan pengaturan Pasal di atas diketahui bahwa pelaksanaan perlindungan konsumen akan memberikan perlindungan kepada konsumen termasuk dalam hal ini perlindungan bagi konsumen uyang mendapatkan produk makanan yang kadaluwarsa. Sebagaimana yang terjadi di Kota Batam dengan banyaknya barang-barang yang beredar di seluruh Supermarket, Minimarket, dan kios/toko yang

\footnotetext{
${ }^{46}$ Ahamdi Miru \& Sutarman Yodo, Hukum Perlindungan Konsumen. Jakarta: PT Rajagrafindo Perkasa, 2011, h. 65
} 
tersebar di 12 kecamatan yang ada, tidak sedikit barang berupa produk makanan yang tersebut sudah jatuh tempo (kadaluwarsa).

Berdasarkan hasil wawancara dan observasi yang telah peneliti lakukan bahwa ada beberapa kecamatan diperoleh informasi, bahwa pelaksanaan perlindungan hukum mengenai perlindungan hukum bagi pihak konsumen yang mendapatkan produk makanan kadaluwarsa sudah dilakukan. Hal ini terlihat dengan adanya pertanggungjawaban yang sudah dijalankan oleh pihak pemilik toko, supermarket dan minimarket yang ada di Kota Batam. Hal demikian tentunya jelas pengaturan yang sudah diatur dalam ketentuan pasal 7 terutama dalam UndangUndang Perlindungan Konsumen secara realisasi sudah dijalankan oleh pelaku usaha yang ada di Kota Batam. Berbagai ganti rugi, kompensasi dan pertanggungjawaban lain sudah dilakukan oleh pihak pemilik toko, sehingga hak-hak konsumen yang sebelumnya masih dilanggar dapat dilindungi dan sengketa hak berkenaan dengan perlindungan konsumen dapat dilakukan secara baik.

Berdasarkan Undang-Undang perlindungan konsumen diketahui bahwa terdapat pengaturan tentang perihal pengawasan yang harus dilakukan oleh badan pengawas yang ditunjuk sehingga dengan pengawasan tersebut diupayakan hukum perlindungan konsumen betul-betul berjalan sesuai dengan apa yang sudah diatur oleh Undang-Undang yang berlaku. Badan pengawas perlindungan konsumen merupakan bagian dari tugas pemerintah dalam melakukan perlindungan hukum terhadap konsumen dan pelaku usaha dalam hal mendapatkan barang atau jasa. Ketika pengawasan dilakukan tentu peredaran produk makanan sebagaimana yang dihadapi oleh masyarakat kota Batam sebagaimana yang ditemukan di lapangan, masyarakat menemukan adanya produk makanan yang sudah kadaluwarsa beredar di supermarket, minimarket dan toko yang ada. Sebagaimana hasil temuan Peneliti di lapangan ditemukannya produk minuman Marjan dalam keadaan sudah kadaluwarsa, berarti dalam hal ini dapat diketahui kenapa ini terjadi. Jika seandainya pengawasan dilakukan secara baik atau secara berkala, maka hal seperti ini tidak akan terjadi. Tetapi dari hasil info dari Dinas Disperindag Kota Batam diketahui bahwa pengawasan di Kota Batam belum terlaksana secara baik karena memang dari personil yang ada masih minim. Sedangkan dari data yang ada luas kota Batam yang tersebar ke pulau-pulau terkadang menyulitkan pelaksanaan pengawasan untuk di lakukan. Seperti contoh misalnya masyarakat belakang Padang yang mengandalkan kendaraan laut, ketika cuaca buruk maka pemantuan untuk ke sana sangat sulit dilakukan. Oleh sebab itu perlu kiranya pengawasan yang sudah ditunjuk sebagai perpanjangtanganan dari pelaksanaan Undang-Undang Perlindungan Konsumen diterapkan sebagaimana tugas dan fungsi yang sudah ditetapkan.

Ketika suatu produk luput dari hasil pemantauan tim pengawas yang sudah ditunjuk, akan berdampak kepada ditemukannya produk yang cacat produk di lapangan. Berkaitan dengan cacat produk dapat ditemukan dalam tiga klasifikasi menurut tahap-tahap produksi, yaitu kerusakan produk, kerusakan desain, dan pemberian informasi yang tidak memadai. Untuk menghindari adanya produk yang cacat atau berbahaya, maka perlu ditetapkan standar minimal yang harus dipedomani dalam memproduksi suatu produk yang layak dan aman untuk dipakai. Usaha inilah yang dimaksud dengan standarisasi yang memuat penerapan aturan-aturan yang teratur bagi kegiatan tertentu untuk kemanfaatan dan dengan kerjasama dari semua pihak yang berkepentingan, khususnya untuk meningkatkan penghematan menyeluruh secara optimum dengan memperhatikan kondisi fungsional dan 
persyaratan keamanan. Hal ini didasarkan pada konsolidasi dari hasil (ilmu) teknologi dan pengalaman.

Sebagaimana pengaturan pidana yang telah diatur secara jelas termasuk perihal pelanggaran yang dilakukan oleh pelaku usaha, baik dengan kesengajaan atau tidak sengaja, maka secara hukum dapat dimintakan pertanggungjawaban secara sanksi pidana. Ketika sanksi pidana ini dilakukan tentunya khusus untuk wilayah Kota Batam tidak akan ditemukan barang produk makanan yang kadaluwarsa di supermarket, minimarket atau di toko sekalipun. Sepanjang hal itu tidak dilakukan, maka perbuatan curang dari pelaku usaha akan tetap ada, sehingga akan berdampak pada kerugian yang ditanggung oleh pihak konsumen selaku orang yang membutuhkan produk tersebut. Jika partisipasi pemerintah dalam hal ini tim pengawas yang ditunjuk tidak melakukan tugasnya secara baik tersebut, maka tentu hal ini akan memberikan dampak kerugian yang makin hari akan semakin banyak diderita oleh konsumen baik individu maupun kelompok. Jadi dibutuhkan dalam hal ini tindakan preventif terhadap pihak-pihak yang terkait dengan pelaksanaan Undang-Undang perlindungan konsumen meliputi pengawas yang sudah ditunjuk oleh pemerintah, Badan Penyelesaian Sengketa Konsumen dan Lembaga Swadaya Masyarakat yang diberikan wewenang untuk itu. Semua ini merupakan bentuk kaitan antara perlindungan hukum sebagaimana teori Philiphus M. Hadjon perlindungan konsumen yang dilakukan oleh konsumen, pelaku usaha, produsen dan pemerintah.

Apabila tindakan produsen menyediakan barang atau jasa untuk konsumen mendapatkan komplein karena tindakannya tersebut menimbulkan kerugian konsumen, maka akan dimintakan tanggungjawab mutlak. Tindakan tanggungjawab ini tentunya akan memberikan tuntutan ganti rugi atau biaya kompensasi kepada pelaku usaha setelah dilakukannya pembuktian. Berdasarkan pengaturan UndangUndang di atas diketahui bahwa pengaturan tentang produk makananan kadaluwarsa dalam Undang-Undang perlindungan konsumen, sebagaimana pasal 4 dalam ayat ini telah menjabarkan bahwa konsumen memiliki hak sebagai sebagai berikut hak atas kenyamanan, keamanan, dan keselamatan dalam mengkonsumsi barang dan/atau jasa; hak untuk memilih barang dan/atau jasa serta mendapatkan barang dan/atau jasa tersebut sesuai dengan nilai tukar dan kondisi serta jaminan yang dijanjikan; hak atas informasi yang benar, jelas, dan jujur mengenai kondisi dan jaminan barang dan/atau jasa; dan hak untuk didengar pendapat dan keluhannya atas barang dan/atau jasa yang digunakan.

Berdasarkan pasal tersebut diketahui bahwa makanan yang kadaluwarsa merupakan bentuk tindakan yang menyebabkan kerugian pada pihak konsumen, baik kesehatannya maupun kerugian secara materi. Seorang konsumen ketika mereka memperoleh barang yang sudah kadaluwarsa (lewat waktu), maka mereka secara ekonomi apa yang diinginkan tentu tidak tercapai, begitu juga bagi yang mengkonsumsi. Namun hal ini tidak tercapai karena makanan itu memberikan dampak negatif bagi yang mengkonsumsinya.

Pelaksanaan Undang-Undang Nomor 8 Tahun 1999 tentang Perlindungan Konsumen, bahwa produk makanan kadaluarsa memiliki dasar hukum yang jelas, sehingga diperlukan ketentuan produk makanan yang dikategorikan kadaluarsa adalah produk makanan yang ketika dikonsumsi tidak diterima baik oleh tubuh melainkan akan menyebabkan suatu kerugian berupa sakit pada bagian tubuh yang mengkonsumsinya. Hal yang sama juga dipertegas oleh ketentuan Kitab UndangUndang Hukum Pidana tentang sanksi yang harus dikenakan kepada pelaku yang melakkan pelanggaran hak konsumen. Untuk menentukan kadaluarsa atau tidaknya 
suatu produk makanan ditentukan oleh berubah warna, berubah rasa dan menimbulkan efek samping bagi pemakainya. Hal ini juga dapat dibuktikan dengan hasil laboratorium atau dengan melihat label ketentuan produksi makanan tersebut sehingga dengan label tertera, maka dapat diketahui makanan tersebut memiliki kondisi masih bagus dikonsumsi atau tidak bagus untuk dikonsumsi.

\section{Dampak Penerapan Undang-Undang Nomor 8 Tahun 1999 Terhadap Produk Makanan Kadaluwarsa di Kota Batam.}

Berdasarkan keterangan lapangan diperoleh informasi mengenai objek penelitian berkenaan tentang permasalahan dampak penerapan Undang-Undang Nomor 8 Tahun 1999 Tentang Perlindungan Konsumen terhadap produk makanan kadaluwarsa di Kota Batam diantaranya: Pertama, memberikan kenyamanan dan keselamatan konsumen dalam membeli produk makanan. Hal ini sebagaimana dimuat dalam Undang-Undang Perlindungan konsumen Pasal 4 menyatakan bahwa "hak atas kenyamanan, keamanan, dan keselamatan dalam mengkonsumsi barang dan/atau jasa; hak untuk memilih barang dan/atau jasa serta mendapatkan barang dan/atau jasa tersebut sesuai dengan nilai tukar dan kondisi serta jaminan yang dijanjikan; hak atas informasi yang benar, jelas, dan jujur mengenai kondisi dan jaminan barang dan/atau jasa; hak untuk didengar pendapat dan keluhannya atas barang dan/atau jasa yang digunakan. Berdasarkan pengaturan tersebut, maka telah diatur secara jelas perihal hak konsumen menyangkut permasalahan memperoleh produk makanan secara aman dan tidak menimbulkan efek samping yang membahayakan kesehatan, serta ketika memberikan efek negatif maka konsumen harus didengan pendapatnya berkenaan dengan keluhan tersebut. Melihat kepada hasil lapangan yang ada, tindakan konsumen untuk melakukan komplein kepada pihak toko merupakan hak baginya karena terdapat bagian hak konsumen yang belum didapatkan setelah membeli barang yang disediakan oleh pelaku usaha.

Adanya kerugian yang diderita oleh konsumen, tentunya akan memberi dampak kepada pertanggungjawaban kepada pelaku usaha. Sebagaimana diatur dalam Pasal 10 pelaku usaha dalam menawarkan barang dan/atau jasa yang ditujukan untuk diperdagangkan dilarang menawarkan, mempromosikan, mengiklankan atau membuat pernyataan yang tidak benar atau menyesatkan mengenai harga suatu barang dan/atau jasa; kegunaan suatu barang dan/atau jasa; kondisi, tanggungan, jaminan, hak atau ganti rugi atas suatu barang dan/atau jasa; tawaran potongan harga atau hadiah menarik yang ditawarkan; dan bahaya penggunaan barang dan/atau jasa. Berdasarkan Pasal tersebut diketahui bahwa pelaku usaha dilarang untuk melakukan tindakan yang menawarkan, mempromosikan barang yang memberikan dampak negatif atau menimbulkan bahaya kepada konsumen.

Kedua, adanya perlindungan hukum bagi konsumen akan memberikan kepastian hukum bagi konsumen maupun bagi pelaku usaha. Sebagaimana diatur dalam Pasal 6 dan 7 Undang-Undang Perlindungan Konsumen telah dijelaskan bahwa adanya pengaturan hak dan kewajiban pelaku usaha. Salah satu hak pelaku usaha adalah hak untuk menerima pembayaran yang sesuai dengan kesepakatan mengenai kondisi dan nilai tukar barang dan/atau jasa yang diperdagangkan. Namun hak tersebut haruslah sesuai dengan jenis dan kualitas barang yang diperjualbelikan. Misalnya saja ketika menjual makanan tentu secara harga dan kualitas tentu sesuai dengan kualitas dan fungsi barang tersebut dan tidak menimbulkan efek negatif bagi konsumen. Sedangkan kewajibannya sebagaimana Pasal 7 butir b, menyatakan 
bahwa pelaku usaha wajib memberikan informasi yang benar, jelas dan jujur mengenai kondisi dan jaminan barang dan/atau jasa serta memberi penjelasan penggunaan, perbaikan dan pemeliharaan. Selanjutnya butir f menyatakan bahwa pelaku usaha wajib memberi kompensasi, ganti rugi dan/atau penggantian atas kerugian akibat penggunaan, pemakaian dan pemanfaatan barang dan/atau jasa yang diperdagangkan.

Sebagaimana yang terjadi di lapangan tindakan yang dilakukan oleh Supermarket Top 100 Batu Aji, Toko Aciu dan toko lain yang Penulis wawancarai dan telah dilakukan observasi. Berdasarkan hasil observasi terdapat beberapa kesalahan, berupa luputnya pengawasan barang produk makanan sehingga barang yang kadaluwarsa sampai ke tangan konsumen. Namun sebagaimana telah diatur Undang-Undang Perlindungan Konsumen mereka telah menuanaikan kewajiban memberikan perlindungan kepada konsumen dalam bentuk memberikan ganti rugi atas kerugian konsumen dengan cara penggantian barang, ganti rugi pengobatan dan bentuk lain yang disetujui dengan pihak konsumen.

Di samping itu, sebagaimana bunyi pasal 67 sampai dengan pasal 96 UndangUndang perlindungan konsumen, telah diatur tentang penyelenggaraan keamanan pangan yang dilakukan melalui sanitasi pangan, pengaturan terhadap bahan tambahan Pangan, pengaturan terhadap pangan produk rekayasa genetik, pengaturan terhadap iradiasi pangan, penetapan standar kemasan pangan, pemberian jaminan keamanan pangan dan mutu pangan serta jaminan produk halal bagi yang dipersyaratkan.

Selanjutnya dalam pasal 96 sampai 107 mengatur tentang kewajiban mencantumkan label di dalam dan atau pada kemasan pangan, pencantuman label tersebut ditulis atau dicetak dengan menggunakan bahasa Indonesia serta memuat paling sedikit keterangan mengenai:nama produk, daftar bahan yang digunakan, berat bersih atau isi bersih, nama dan alamat pihak yang memproduksi atau mengimpor, halal bagi yang dipersyaratkan, tanggal dan kode produksi, tanggal, bulan dan tahun kedaluwarsa, nomor izin edar bagi pangan olahan dan asal usul bahan pangan. Keseluruhan aturan dalam Undang-Undang tersebut memberikan sanksi berupa sanksi administratif yaitu berupa: denda; penghentian sementara dari kegiatan, produksi, dan/atau peredaran; penarikan pangan dari peredaran oleh produsen; ganti rugi; dan/atau pencabutan izin.

Ketentuan lebih lanjut mengenai jenis, besaran denda, tata cara, dan mekanisme pengenaan sanksi administratif sebagaimana dimaksud dalam UndangUndang tersebut diatur dalam Peraturan Pemerintah ${ }^{47}$ Berdasarkan realisasi yang terjadi di lapangan beberapa kasus yang terjadi berkenaan dengan pelaksanaan produk makanan yang kadaluwarsa sehingga sebagian hak konsumen dilanggar oleh pihak pelaku usaha, dimintakan tanggungjawab atas kerugian konsumen dengan memberikan sanksi administrasi berupa pembayaran ganti rugi kepada pihak konsumen dalam bentuk penggantian dengan barang yang tidak kadaluwarsa, membayar biaya pengobatan, penarikan pangan dari peredaran, mengembalikan barang kadaluwarsa kepada pihak penjual dan memusnahkan barang tersebut jika barang kadaluwarsa dalam jumlah yang sedikit.

Ketiga, dengan adanya ketentuan Undang-Undang perlindungan konsumen, maka pelaku usaha dimintakan untuk lebih berhati-hati dalam menyediakan atau menawarkan barang dagangan dengan maksud mengelabui atau membuat tindakan

${ }^{47}$ Undang-Undang Nomor 18 Tahun 2012 tentang Pangan 
tidak senang, maka sesuai dengan ketentuan perundang-undangan akan diminta pertanggungjawaban pelaku secara mutlak. Baik dikenakan sebatas sanksi pidana maupun akan dikanakan sanksi perdata. Hal ini diperkuat dengan ketentuan sanksi yang akan dikenakan kepada pelaku usaha sebagaimana diatur dalam Pasal 62 (1) Pelaku usaha yang melanggar ketentuan sebagaimana dimaksud dalam Pasal 8, Pasal 9, Pasal 10, Pasal 13 ayat (2), Pasal 15, Pasal 17 ayat (1) huruf a, huruf b, huruf c, huruf e, ayat (2) dan Pasal 18 dipidana dengan pidana penjara paling lama 5 (lima) tahun atau pidana denda paling banyak Rp.2.000.000.000,- (dua miliar rupiah). Serta ketentuan Pasal 63 Undang-Undang Perlindungan Konsumen yang menyebutkan bahwa sanksi pidana sebagaimana dimaksud dalam Pasal 62, dapat dijatuhkan hukuman tambahan, berupa perampasan barang tertentu; pengumuman keputusan hakim; pembayaran ganti rugi; perintah penghentian kegiatan tertentu yang menyebabkan timbulnya kerugian konsumen; kewajiban penarikan barang dari peredaran; atau pencabutan izin usaha.

Adapun tujuan penyelenggaraan dan pengaturan perlindungan konsumen adalah untuk meningkatkan martabat dan kesadaran konsumen, dan secara tidak langsung mendorong pelaku usaha dalam menyelenggarakan kegiatan usahanya dengan penuh rasa tanggung jawab. Pengaturan perlindungan konsumen dapat dilakukan dengan cara menciptakan sistem perlindungan konsumen yang mengandung akses dan informasi, serta menjamin kepastian hukum; melindungi kepentingan konsumen pada khususnya dan kepentingan seluruh pelaku usaha pada umumnya; meningkatkan kualitas barang dan pelayanan jasa; memberikan perlindungan kepada konsumen dari praktik usaha yangmenipu dan menyesatkan; dan memadukan penyelenggaraan, pengembangan dan pengaturan perlindungan konsumen dengan bidang-bidang perlindungan pada bidang-bidang lainnya. ${ }^{48}$

Menurut Zen Umar Purba mendefinisikan bahwa, kerangka umum tentang sendi-sendi pokok pengaturan perlindungan konsumen yaitu: ${ }^{49}$ meliputi kesederajatan antara konsumen dan pelaku usaha; konsumen mempunyai hak; pelaku usaha mempunyai kewajiban; pengaturan tentang perlindungan konsumen berkontribusi pada pembangunan nasional; perlindungan konsumen dalam iklim bisnis yang sehat; keterbukaan dalam promosi barang atau jasa; pemerintah perlu berperan aktif; masyarakat juga perlu berperan serta; perlindungan konsumen memerlukan terobosan hukum dalam berbagai bidang dan konsep perlindungan konsumen memerlukan pembinaan sikap. Kata perlindungan menurut Kamus Umum Bahasa Indonesia berarti tempat berlindung atau merupakan perbuatan melindungi, seperti memberi perlindungan terhadap orang yang lemah. Menurut Sudikno Mertokusumo menjelaskan bahwa yang dimaksud dengan hukum adalah kumpulan peraturan atau kaedah yang mempunyai isi yang bersifat umum dan normatif, umum karena berlaku bagi setiap orang dan normatif karena menentukan apa yang seyogyanya dilakukan, dan apa yang tidak boleh dilakukan atau harus dilakukan serta menentukan bagaimana caranya melaksanakan kepatuhan pada kaedahkaedah..$^{50}$

Berdasarkan teori perlindungan hukum sebagaimana teori perlindungan hukum yang dikemukanakan oleh Philiphus M. Hadjon menyebutkan bahwa sarana

\footnotetext{
${ }^{48}$ Ibid, h. 18

${ }^{49}$ Happy Susanto, 2008, Hak-hak Konsumen Jika Diragukan, Jakarta-Selatan: Transmedia Pustaka. 2008, h. 5

${ }^{50}$ Sudikno Mertokusumo, Mengenal Hukum Suatu Pengantar, Yogyakarta: Liberty, 1991, h. 38
} 
perlindungan hukum terhadap konsumen yang mengkonsumsi produk makanan kadaluwarsa terdiri dari sarana perlindungan hukum preventif dan represif, dalam penelitian ini perlindungan hukum preventif dan represif dilakukan oleh pemerintah melalui Dinas Perindustrian dan Perdagangan serta dinas-dinas terkait lainnya. Hal ini tentu dilakukan dengan mengajukan gugatan ke Badan Penyelesaian Sengketa oleh konsumen atau perwakilan konsumen. Sehingga dengan gugatan yang sudah diterima pihak Badan Penyelesaian Sengketa Konsumen akan melakukan pemanggilan sebagaimana layaknya peradilan biasa dengan melibatkan konsumen, pelaku usaha, badan pengawas, masyarakat dan tokoh masyarakat sebagai bukti bahwa memang terjadi pelanggaran sengketa konsumen sesuai dengan gugatan yang ada. Hasil dari BPSK akan melahirkan putusan baik berupa sanksi perdata (administrasi/perizinan) atau berupa sanksi pidana (penjara dan denda).

Perlindungan preventif dilakukan oleh pengawas yang ditunjuk untuk mengawasi pelaksanaan barang-barang yang beredar di beberapa supermarket, minimarket dan toko-toko yang ada di Kota Batam. Pemerintah Kota Batam dalam hal ini belum menggunakan kebijakan otonomi daerahnya untuk mengatur tentang pelindungan hukum terhadap konsumen dari beredarnya produk kadaluarsa di Kota Batam. Sedangkan perlindungan di bidang represif yang harus dilakukan adalah menjalankan sanksi yang ada kepada pelaku usaha yang melakukan `tindakan yang melanggar hak-hak konsumen terutama dalam hal produk makanan kadaluwarsa. Memfungsikan penyelesaian sengketa konsumen ke ranah penyelesaian baik peradilan maupun pra peradilan. Serta melibatkan lembaga swadaya masyarakat dalam menanggulangi permasalahan yang ada berkenaan tentang pelaksanaan pengawasan dari beredarnya produk makanan yang sudah kadaluwarsa di supermarket, minimarket dan toko-toko yang ada di Kota Batam.

Keempat, pihak manapun baik pelaku usaha, konsumen antara, maupun konsumen akhir akan diminta pertanggungjawabannya, sehingga menyebabkan pihak lain tidak mendapatkan kerugian baik secara moril maupun materil. Berdasarkan hasil wawancara yang dilakukan Peneliti dari beberapa pedagang, Peneliti menemukan beberapa faktor yang menyebabkan pedagang mengedarkan barangbarang kadaluwarsa diantaranya disebabkan oleh faktor ketidaktahuan akan kondisi barang. Pedagang yang awalnya membeli atau mengorder barang dagangannya akan langsung menjual kembali barang tersebut tanpa mengecek kembali, barang yang telah lama dijajakan akan tetap dijajakan tanpa melihat apakah barang tersebut sudah sampai masa kadaluwarsanya. Beberapa contoh barang kadaluwarsa yang sering dijajahkan oleh pedagang berupa produk mie instan, produk susu kemasan, produk minuman botolan, produk biskuit, produk bumbu-bumbu masak, dan produk makanan ringan. Namun produk kadaluwarsa yang paling banyak ditemukan adalah pada produk mie instan. Berdasarkan kajian di lapangan seperti yang telah penulis teliti ditemukan produk makanan kadaluwarsa berupa makanan kaleng (makarel produk naraya), susu borjuis, kue bolu coklat, jely drink, dan lain-lain.

Faktor lain disebabkan oleh karena tidak adanya komplain dari konsumen, sehingga pedagang merasa aman ketika makanan kadaluwarsa mereka perjualbelikan. Ketika tidak adanya konsumen yang komplein, maka pihak pedagang selaku pelaku usaha akan lalai memperhatikan barang dagangannya yang akan dijual. Faktor lainnya tidak ingin rugi, maksudnya pedagang tetap menjual makanan kadaluwarsa selama bentuk dagangannya tersebut masih layak untuk dijual dikarenakan tidak ingin rugi. Faktor lainnya juga disebabkan oleh pedagang tidak mengetahui jika menjual makanan kadaluwarsa merupakan pelanggaran hukum. 
Beberapa pedagang terkadang mengakui bahwa ia mengetahui bahwa makanan kadaluwarsa tidak layak untuk di konsumsi dan berbahaya untuk kesehatan akan tetapi mereka tidak mengetahui jika hal tersebut merupakan pelanggaran hukum.

Beberapa faktor yang menyebabkan konsumen sebagai korban tidak melaporkan kejadian tersebut kepada pihak terkait dengan beberapa alasan diantaranya konsumen menganggap hal tersebut adalah hal sepeleh dan tidak perlu di besar-besarkan, jika konsumen hanya membeli satu atau dua barang saja yang harganya bahkan tidak lebih dari Rp.5000,-; konsumen menjaga hubungan baik dengan pedagang yang merupakan tetangga atau dekat dengan mereka; konsumen tidak mau repot untuk mengembalikan lagi atau melaporkannya ke pihak berwajib; konsumen merasa kasihan kepada pedagang; konsumen beranggapan akan lebih banyak biaya yang harus di keluarkan jika melaporkannya kepada yang berwajib. Beberapa konsumen beranggapan bahwa jika hanya karna makanan kadaluwarsa yang harganya hanya berkisar Rp. 5000,- ia harus mengeluarkan dana lebih berkalikali lipat dari harga makanan tersebut konsumen merasa di rugikan.

\section{Solusi dari Undang-Undang Nomor 8 Tahun 1999 Terhadap Dampak Negatif Penggunaan Produk Makanan Kadaluwarsa di Kota Batam}

Hasil wawancara tersebut memberikan informasi bahwa menurut pemilik toko menerangkan bahwa selama berjualan memang pernah mendapati makanan yang dijual kadaluwarsa. Terhadap hal tersebut, maka tindakan yang dilakukan adalah mengembalikan barang tersebut kepada pihak pemilik barang. Hal ini dilakukan kalau seandainya barang yang kadaluwarsa tersebut masih banyak, tetapi kalau barangnya sedikit 2 (dua) atau 3 (tiga) buah biasanya kami buang saja. Namun memang tidak jarang produk makanan yang didapat dari pihak grosir khususnya makanan, didapat barang yang $1 / 2$ bulan akan kadaluwarsa. Ketika ini terjadi biasanya pihak kami membeli barang tersebut dalam jumlah sedikit, sehinggaa barang tersebut tidak menumpuk. Sebelum barang itu jatuh tempo, biasanya untuk jangka waktu beberapa harus biasanya kami akan mengobral barang tersebut dengan menjual agak murah. Hal ini dengan tujuan agar barang kadaluarsa tersebut tidak sampai jatuh tempo (kadaluwarsa). Menurut keterangan pemiliki toko juga mengatakan bahwa selama beroperasi sejak berdiri toko ini, pernah mendapati adanya komplein dari pihak konsumen yang mendapatkan barang yang sudah kadaluwarsa. Namun dengan penyelesaian secara kekeluargaan, pemilik toko memberikan tanggungjawab kepada pihak konsumen atas kerugiannya, berupa mengganti dengan barang yang masih bagus. Menurut Pemilik toko mereka menjual makanan tersebut karena atas dasar ketidaktahuan bahwa barang tersebut kadaluwarsa. Pada waktu itu jenis makanan yang kadaluwarsa adalah makanan Sardines. Pemilik toko menyadari bahwa, memang pada waktu itu kesalahan yang terjadi adalah memang oleh pihak kami sendiri, karena memang lupa melihat pajangan barang jualan pada waktu itu. Tetapi dengan penyelesaian yang secara kekeluargaan dapat diselesaikan, makanya urusan permasalahan tidak sampai kepada permasalahan yang mengarah kepada pertikaian. Makanya dengan permasalahan tersebut, menjadi suatu pelajaran bagi kami bahwa dalam memajang makanan harus dilakukan pengecekan barang yang diperjualbelikan dengan ketentuan kebolehan untuk dikonsumsi atau tidak dibolehkan.

Keterangan seperti di atas Penulis dapatkan melalui wawancara langsung dengan pihak penjual yang mewakili supermarket, minimarket dan toko/swalayan yang ada di Kota Batam. Ada juga keterangan pemilik toko menyebutkan bahwa untuk menghindari kesalahan dari pihak toko membeli barang dengan batas 
kadaluwarsa yang berjangka waktu masih lama, misalnya masih 3-6 bulan kadaluwarsa. Sementara terhadap kadaluwarsa mencapai 1-2 bulan, biasanya kami menghabiskan stok yang ada, kalau membeli barang yang baru itupun dalam jumlah yang sedikit. Sehingga dengan demikian. Barang tersebut tidak menumpuk lama di toko dan kemungkinan kadaluwarsa dapat diantisipasi. Kemudian jika seandainya pihak pemasok (pelaku usaha) tidak mau tanggung jawab, maka terhadap barang kadaluwarsa seperti itu, akan dilakukan pemusnahan terhadap barang tersebut dan kerugian tentu akan ditanggung oleh kami (pemilik toko) karena memang barang kadaluwarsa bukan disebabkan oleh pihak pemasok barang melainkan karena lamanya barang tersebut menumpuk di toko kami (pemilik toko).

Keterangan lainnya juga didapatkan berupa antisipasi yang dilakukan oleh pihak toko/pemilik supermarket terhadap barang kadaluwarsa adalah dengan meningkatkan kehati-hatian terutama terhadap produk makanan yang sudah menumpuk lama di toko. Berdasarkan keterangan dari responden penelitian menyatakan bahwa ketika didapatkan produk yang kadaluwarsa, maka kami akan mengembalikannya kepada pihak penjual, karena memang sebelum kami memutuskan untuk melakukan atau tidak untuk melakukan akad jual beli, maka kami akan menyepakati bahwa kalau barang yang dibeli terlihat cacat, maka kami akan mengembalikan barang tersebut. Pihak penjual pun menyetujui hal demikian sehingga baru transaksi jual beli dilakukan. Jika seandainya barang yang kadaluwarsa tersebut sampai ke tangan pembeli (konsumen), maka pihak kami akan bertanggungjawab terhadap kerugian konsumen dengan ketentuan konsumen membawa bukti kadaluwarsa tersebut ke tempat kami. Adapun bentuk pertanggungjawaban yang kami lakukan berupa tanggung jawab ganti rugi atas kerugian konsumen dengan cara mengganti dengan barang baru yang layak konsumsi, mebayar biaya pengobatan, meminta pertanggungjawaban kepada pihak pemasok barang bersamaan dengan mengmebalikan barang kadaluwarsa lain ke penjual pertama. Dengan demikian apa yang dikeluhkan oleh pihak konsumen dapat diantisipasi setelah kesepakatan pertanggungjawaban dilakukan.

Dari hasil wawancara yang ada pihak pemilik toko memberikan arahan bahwa pernah dahulunya terjadi komplein dari pihak pembeli perihal barang yang dijual sudah kadaluwarsa sehingga pada akhirnya pihak pembeli menuntut ke toko kami untuk membayar kerugian atas kerugian yang ditanggung oleh pembeli. Pada akhirnya mereka memberikan pertangungjawaban terkait dengan kasus tersebut. Adapun bentuk pertangungjawaban yang mereka berikan adalah bentuk perjanjian penggantian barang yang layak (bisa dikonsumsi), membayar pengobatan kalau seandainya sudah dikonsumsi oleh pihak konsumen, atau memberikan ganti rugi sesuai dengan yang diperjanjikan sehingga dengan upaya tersebut tidak terjadi pertikaian antara pihak toko selaku pelaku usaha dengan pihak pembeli selaku konsumen.

Di samping diperoleh informasi dari wawancara, Penulis juga memperoleh informasi berupa hasil observasi ke beberapa supermarket, Minimarket dan Toko/Swalayan yang dijadikan objek penelitian. Dari hasil pengamatan Penulis diperoleh informasi bahwa produk makanan kadaluwarsa oleh pihak toko/pemilik, maka sebagaimana Undang-Undang Perlindungan konsumen mereka akan memberikan tanggungjawab atas kerugian pihak konsumen. Tanggungjawab yang diberikan berupa tanggungjawab mengobati konsumen tersebut dengan menanggung biaya pengobatan, mengganti dengan produk yang tidak kadaluwarsa, atau memberikan pengembalian harga yang sudah dibayarkan atau sesuai dengan 
kesepakatan yang disepakati oleh keduanya. Dengan adanya tindakan tersebut maka pihak pelaku usaha dengan pihak konsumen menganggap permasalahan ini sudah selesai. Jadi dengan adanya prinsip tanggungjawab mutlak terhadap kerugian yang ditanggung oleh pihak pelaku usaha akan memberikan solusi atas dampak negatif yang timbul bagi konsumen yang mendapati produk makanan kadaluwarsa di Kota Batam. Tanggungjawab yang dberikan oleh pemilik toko merupakan bukti bahwa pemilik toko sudah berjiwa besar dalam memberikan/ menunaikan hak-hak konsumen yang telah dia rampas dari diri konsumen itu sendiri. Namun karena ganti rugi yang diberikan disetujui oleh kedua belah pihak, maka tidak terjadi pertikaian dalam hal ini dan kesepakatan untuk memberikan ganti rugi atas kerugian konsumen disetujui oleh keduanya.

Kejadian ini terjadi pada saat membeli produk agar-agar ini, maka pihak pembeli tergesa-gesa membeli produk tersebut dengan alasan pihak pembeli tergesagesa membeli dengan alasan anaknya menangis meminta dibelikan produk ini.Barang tersebut tidak dicek terlebih dahulu oleh pihak konsumen, begitu juga yang terjadi pada pihak toko Acui, di mana pembeli tidak memperhatikan label yang ada pada kemasan karena terburu-buru mau membeli, sehingga mereka salah mendapatkan barang yang tidak sesuai dengan kualitas yang bagus. Setelah anakanak mengkonsumsi makanan ini mereka merasakan sakit perut, mual, mencret, panas tinggi, sehingga dilarikanlah si anak ke rumah sakit. Setelah diobati oleh pihak rumah sakit, maka diperoleh info bahwa si anak keracunan makanan yang baru saja dia konsumsi. Mendengar hal demikian pihak orang tua mendatangi pihak penjual, maka ditemukan hasil pihak toko mau mengakui kesalahan yang dilakukan. Dan mereka dengan spontan menjawab bahwa dia akan bertanggungjawab sepenuhnya untuk mengobati si anak sampai si anak sembuh.

Melihat hal demikian tentunya diketahui bahwa pelanggaran yang dilakukan oleh pihak pelaku usaha atas kelalaian nya harus diminta pertanggungjawaban atas kesalahan nya. Ketika mereka tidak mau mempertanggungjawabkan tindakan nya, maka konsumen punya hak untuk melaporkan permasalahan ini ke pihak yang lebih tinggi. Dengan adanya pertanggungjawaban yang diberikan oleh pihak pemilik toko tersebut, maka perselisihan berkenaan tentang pelanggaran hak konsumen tidak berujung kepada sengketa konsumen. Dengan tindakan tersebut, maka konsumen pembeli dari dua toko tersebut, baik toko sempurna Jaya maupun toko Acui, merasa lega dan mereka berjanji untuk kedepannya akan lebih berhati-hati untuk menjual barang pada supermarket atau toko mereka khususnya produk makanan, dari pelanggaran hak konsumen yang mendapatkan produk yang sudah kadaluwarsa. Dengan perlakuan tersebut, kedua toko ini mengutarakan solusi kedepannya yang akan mereka lakukan sehingga kelalaian mereka khususnya dalam hal mendapatkan barang yang kadaluwarsa tidak terjadi adalah dengan cara meningkatkan kehatihatian dalam membeli barang khususnya produk makanan dari pihak pemasok barang, sering melakukan pengecekan terhadap jenis produk makanan yang sudah lama dipajang jangan sampai luput dari pengawasan pihak pemilik/penjaga toko atau supermarket. Karena apabila ini dilalaikan akan berakibat fatal menghilangkan citra baik toko atau supermarket di mata masyarakat.

Melihat kepada permasalahan demikian, diketahui bahwa kesalahan memilih makanan yang kadaluwarsa berawal dari kesalahan konsumen dan berlanjut menjadi kesalahan pihak penjual selaku pelaku usaha. Pembeli yang pintar, tentu sebelum memutuskan membeli atau tidaknya barang-barang produk makanan, mereka terlebih dahulu memeriksa kondisi barang tersebut, terutama dalam hal memeriksa kondisi 
barang kadaluwarsa atau tidak, memeriksa kemasan rusak atau tidak, memeriksa bentuk atau bau dari produk makanan yang akan dibeli. Semakin jeli seorang konsumen membeli, maka akan semakin kecil peluang untuk mendapatkan barang kadaluwarsa, dan sebaliknya.

Dari hasil observasi Penulis dengan pihak penjual toko Acuan tersebut, diperoleh informasi bahwa pihak toko mengalami suatu hal yang sangat buruk berupa menjual barang yang sudah kadaluwarsa berupa makanan makanan susu bubuk yang dikonsumsi oleh anak-anak. Setelah anak-anak mengkonsumsi makanan ini mereka merasakan sakit perut, mual, mencret, panas tinggi, sehingga dilarikan lah si anak ke rumah sakit. Setelah diobati oleh pihak rumah sakit, maka diperoleh info bahwa si anak keracunan makanan yang baru saja dia konsumsi. Mendengar hal demikian pihak orang tua mendatangi pihak penjual, maka ditemukan hasil pihak toko mau mengakui kesalahan yang dilakukan. Dan mereka dengan spontan menjawab bahwa dia akan bertanggungjawab sepenuhnya untuk mengobati si anak sampai si anak sembuh. Melihat hal tersebut, diketahui bahwa tanggungjawab yang diberikan oleh pelaku usaha terhadap pihak konsumen, terlihat lah dalam hal ini pihak pelaku usaha sudah menjalankan ketentuan yang berlaku.

Berkaitan dengan hal tersebut telah disahkan Undang-Undang No. 8 Tahun 1999 tentang Perlindungan Konsumen. Dengan demikian, maka terdapat 4 (empat) alasan pokok mengapa konsumen harus dilindungi antara lain: ${ }^{51}$ melindungi konsumen sama artinya dengan melindungi seluruh bangsa sebagaimana yang diamanatkan oleh tujuan pembangunan nasional menurut Pembukaan UndangUndang Dasar Republik Indonesia 1945; melindungi konsumen perlu untuk menghindarkan konsumen dari dampak negatif penggunaan teknologi; melindungi konsumen perlu untuk menciptakan iklim persaingan yang sehat jasmani dan rohani bagi para pelaku usaha untuk menjaga kesinambungan pembangunan nasional; dan melindungi konsumen perlu untuk menjamin dana pembangunan yang bersumber dari masyarakat konsumen.

Karena hukum perlindungan konsumen berada dalam bidang perekonomian khususnya berkaitan dengan menjalankan bisnis, maka hukum perlindungan konsumen termasuk ke dalam hukum ekonomi khususnya hukum bisnis. Pada hukum perlindungan konsumen dipersoalkan bagaimana ketentuanketentuan hukum yang berkaitan dengan menjalankan bisnis sehingga tidak merugikan konsumen dan sebaliknya bagaimana konsumen dapat memperoleh perlindungan hukum atas hakhaknya sebagai konsumen.

Berdasarkan hasil pembahasan yang ada, maka solusi yang dapat dilakukan untuk mengatasi dampak negatif akibat penggunaan produk makanan kadaluwarsa di Kota Batam diantaranya adalah: Pertama, memperkuat pelaksanaan tanggungjawab mutlak (strick lialibility) terhadap pelaku usaha (penjual) yang melakukan pelanggaran Undang-Undang konsumen terutama dalam hal menjajakan barang berupa produk makanan yang sudah kadaluwarsa; Kedua, menerapkan audit serta pengawasan terhadap pelaku usaha, khususnya terhadap distributor selaku pemasok barang; Ketiga, menerapkan teori efektivitas hukum oleh Soerjono Soekanto, yang menerangkan bahwa efektifitas hukum dipengaruhi oleh faktor hukum itu sendiri, faktor penegak hukum, faktor masyarakat dan faktor budaya.

Penegakan hukum (law enforcement) dalam arti luas mencakup kegiatan untuk melaksanakan dan menerapkan hukum seta melakukan tindakan hukum

${ }^{51}$ Erna Widjajati, op.cit., h. 2 
terhadap setiap pelanggaran atau penyimpangan hukum yang dilakukan oleh subyek hukum, baik melalui prosedur peradilan maupun melalui abitrase dan mekanisme penyelesaian sengketa lainnya (Alternative despute or conflicts resolution). ${ }^{52}$

Dalam pengertian yang lebih luas, kegiatan penegakan hukum mencakup pula segala aktivitas yang dimaksudkan agar hukum sebagai perangkat kaidah normatif yang mengatur dan mengikat pada subjek hukum dalam segala aspek kehidupan bermasyarakat dan bernegara benar-benar ditaati dan sungguh-sungguh dijalankan sebagaimana mestinya. ${ }^{53}$ Penegakan hukum dalam arti sempit menyangkut kegiatan penindakan terhadap setiap pelanggaran atau penyimpangan terhadap peraturan perundang-undangan, khususnya melalui proses peradilan pidana yang melibatkan peran serta aparat kepolisian, kejaksaan, advokat atau pengacara dan badan-badan peradilan karena itu aktor-aktor utama yang peranannya sangat menonjol dalam proses penegakan hukum adalah polisi, jaksa, pengacara dan hakim. ${ }^{54}$

Secara konsepsional, maka arti penegakan hukum terletak pada kegiatan menyelesaikan hubungan nilai-nilai yang terjabarkan di dalam kaidah-kaidah yang mantap dan mengejawantahkan dan sikap tindak sebagai rangkaian penjabaran nilai tahap akhir, untuk menciptakan, memelihara dan mempertahankan kedamaian pergaulan hidup. ${ }^{55}$ Selanjutnya menurut Soerjono Soekanto mendefinisikan bahwa, masalah pokok dari penegakan hukum sebenarnya terletak pada faktor-faktor yang mungkin memengaruhinya, yaitu: ${ }^{56}$ Pertama, faktor hukumnya sendiri yaitu berupa Undang-Undang; di mana praktik penyelenggaraan hukum di lapangan ada kalanya terjadi pertentangan antara kepastian hukum dan keadilan, hal ini disebabkan oleh konsepsi keadilan merupakan suatu rumusan yang bersifat abstrak, sedangkan kepastian hukum merupakan suatu prosedur yang telah ditentukan secara normatif. Justru itu, suatu kebijakan atau tindakan yang tidak sepenuhnya berdasar hukum merupakan sesuatu yang dapat dibenarkan sepanjang kebijakan atau tindakan itu tidak bertentangan dengan hukum. Maka pada hakikatnya penyelenggaraan hukum bukan hanya mencakup law enforcement, namun juga peace maintenance, karena penyelenggaraan hukum sesungguhnya merupakan proses penyerasian antara nilai kaedah dan pola perilaku nyata yang bertujuan untuk mencapai kedamaian. Kedua, faktor penegak hukum, yaitu pihak-pihak yang membentuk maupun yang menerapkan hukum; di mana fungsi hukum, mentalitas atau kepribadian petugas penegak hukum memainkan peranan penting, kalau peraturan sudah baik, tetapi kualitas petugas kurang baik, ada masalah. Oleh karena itu, salah satu kunci keberhasilan dalam penegakan hukum adalah mentalitas atau kepribadian penegak hukum. Ketiga, faktor sarana atau fasilitas yang mendukung penegakan hukum; di mana faktor ini mencakup perangkat lunak dan perangkat keras, salah satu contoh perangkat lunak adalah pendidikan. Pendidikan yang diterima oleh Polisi dewasa ini cenderung pada hal-hal yang praktis konvensional, sehingga dalam banyak hal polisi mengalami hambatan di dalam tujuannya, diantaranya adalah pengetahuan tentang kejahatan computer, dalam tindak pidana khusus yang selama ini masih diberikan

\footnotetext{
${ }^{52}$ Jimly Asshidiqie, Menuju Negara Hukum yang Demokrasi, Jakarta: PT. Bhuana Ilmu Populer, 2009, H. 22

${ }^{53}$ Ibid. ,

${ }^{54}$ Ibid. ,

${ }^{55}$ Soerjono Soekanto, Teori Sosiologi Tentang Perubahan Sosial, Surabaya: Ghalia Indonesia. 1983, h. 2

${ }^{56}$ Soerjono Soekanto, Faktor-Faktor yang Mempengaruhi Penegeakan Hukum, Cetakan Kelima, Jakarta: Raja Grafindo Persada. 2004, h. 42
} 
wewenang kepada jaksa, hal tersebut karena secara teknis yuridis polisi dianggap belum mampu dan belum siap. Walaupun disadari pula bahwa tugas yang harus diemban oleh polisi begitu luas dan banyak. Keempat, faktor masyarakat, yaitu lingkungan di mana hukum tersebut berlaku atau diterapkan; bahwa penegak hukum berasal dari masyarakat dan bertujuan untuk mencapai kedamaian di dalam masyarakat. Setiap warga masyarakat atau kelompok sedikit banyaknya mempunyai kesadaran hukum, persoalan yang timbul adalah taraf kepatuhan hukum, yaitu kepatuhan hukum yang tinggi, sedang, atau kurang. Adanya derajat kepatuhan hukum masyarakat terhadap hukum, merupakan salah satu indicator berfungsinya hukum yang bersangkutan. Kelima, faktor kebudayaan, yaitu sebagai hasil karya, cipta dan rasa yang didasarkan pada karsa manusia di dalam pergaulan hidup.

Berdasarkan kajian teori efektifitas hukum oleh Soerjono Soekanto, menyebutkan bahwa masalah pokok dari penegakan hukum sebenarnya terletak pada faktor-faktor yang mungkin memengaruhinya, yaitu: Pertama, faktor hukumnya sendiri yaitu berupa Undang-Undang. Kepastian hukum merupakan suatu prosedur yang telah ditentukan secara normatif. Kebijakan atau tindakan yang tidak sepenuhnya berdasarkan hukum berlaku dan tidak bertentangan dengan UndangUndang yang ada. Kedua, faktor penegak hukum, yaitu pihak-pihak yang membentuk maupun yang menerapkan hukum. Artinya fungsi hukum, mentalitas atau kepribadian petugas penegak hukum dalam hal menjalankan hukum perlindungan konsumen memainkan peranan penting, kalau peraturan sudah baik, tetapi kualitas petugas kurang baik, ada masalah. Ketiga, faktor sarana atau fasilitas yang mendukung penegakan hukum; hal ini mencakup adanya pendidikan. Keempat, faktor masyarakat, yaitu lingkungan di mana hukum tersebut berlaku atau diterapkan. Penegak hukum berasal dari masyarakat dan bertujuan untuk mencapai kedamaian di dalam masyarakat. Kelima, faktor kebudayaan, yaitu sebagai hasil karya, cipta dan rasa yang didasarkan pada karsa manusia di dalam pergaulan hidup. ${ }^{57}$ Berdasarkan konsep kebudayaan sehari-hari, orang begitu sering membicarakan soal kebudayaan. Kebudayaan menurut Soerjono Soekanto, mempunyai fungsi yang sangat besar bagi manusia dan masyarakat, yaitu budaya masyarakat yang harus dikembangkan adalah budaya jeli membeli, teliti, menjadi konsumen yang pintar sehingga kerugian tidak dirasakan ketika membeli produk makanan atau tidak tertipu dengan barang kadaluwarsa.

Solusi lainnya dari teori perlindungan hukum sebagaimana teori perlindungan hukum oleh Philiphus $M$. Hadjon yang menyatakan bahwa perlindungan hukum adalah suatu perbuatan dalam rangka melindungi subjek-subjek hukum dengan norma-norma atau Peraturan Perundang-undangan yang berlaku (hukum positif) dan pelaksanaannya dapat dipaksakan dengan suatu sanksi. Menurut Philiphus M. Hadjon, negara Indonesia sebagai negara hukum berdasarkan Pancasila haruslah memberikan perlindungan hukum terhadap warga negara sesuai dengan Pancasila. Oleh karena itu perlindungan hukum berdasarkan Pancasila berarti pengakuan dan perlindungan hukum akan harkat dan martabat manusia atas dasar nilai Ketuhanan Yang Maha Esa, kemanusiaan, persatuan, permusyawaratan, serta keadilan sosial. Nilai-nilai tersebut melahirkan pengakuan dan perlindungan hak

\footnotetext{
${ }^{57}$ Soerjono Soekanto, Faktor-Faktor yang Mempengaruhi Penegeakan Hukum, Cetakan Kelima,
} Jakarta: Raja Grafindo Persada, 2004, Hal. 42 
asasi manusia dalam wadah negara kesatuan yang menjunjung tinggi semangat kekeluargaan dalam mencapai kesejahteraan bersama. ${ }^{58}$

Prinsip perlindungan hukum terhadap tindak pemerintah bertumpu dan bersumber dari konsep tentang pengakuan dan Perlindungan terhadap hak-hak asasi manusia karena menurut sejarahnya di Barat, lahirnya konsep-konsep tentang pengakuan dan perlindung an terhadap hak-hak asasi menusia diarahkan kepada pembatasan-pembatasan dan peletakan kewajiban masyarakat dan pemerintah. ${ }^{59}$

Adapun konsep perlindungan hukum menurut Philiphus M. Hadjon mencakup 2 (dua) sarana yaitu: Pertama, sarana perlindungan hukum preventif. Perlindungan hukum preventif ini, subyek hukum diberikan kesempatan untuk mengajukan keberatan atau pendapat nya sebelum suatu keputusan pemerintah mendapat bentuk yang definitif dengan tujuan mencegah terjadinya sengketa. Kedua, sarana perlindungan hukum represif. Perlindungan hukum yang represif bertujuan untuk menyelesaikan sengketa. Penanganan perlindungan hukum pada konsep ini dilakukan oleh Pengadilan Umum dan Peradilan Administrasi di Indonesia termasuk kategori perlindungan hukum ini.

Perlindungan hukum yang dapat dilakukan untuk menanggulangi peredaran makanan kadaluwarsa di Kota Batam dapat dilakukan dengan melakukan upaya preventif dan upaya represif. Upaya preventif adalah upaya yang dilakukan sebelum terjadinya tindak pidana atau pencegahan dari tindak pidana. Sedangkan upaya represif adalah upaya yang dilakukan setelah terjadinya tindak pidana, di mana hal ini terjadi dengan menindak lanjuti laporan-laporan dari masyarakat. ketika tindakan kesalahan yang dilakukan oleh pelaku usaha menyebabkan pihak konsumen meninggal, maka pertanggungjawaban dapat dilakukan dengan upaya represif membuktikan bahwa kebenaran kesalahan itu memang terjadi akibat kelalaian pelaku usaha.

Beberapa upaya preventif yang dapat dilakukan adalah dengan melibatkan pihak Badan Penyelesaian Sengketa Konsumen dan pihak kepolisian dalam menanggulangi peredaran makanan kadaluwarsa yaitu melakukan pengawasan dan pembinaan kepada pelaku usaha dan konsumen, sidak atau razia ke supermarket, minimarket dan toko-toko perbelanjaan, dapat dilakukan penyitaan terhadap barangbarang yang kedaluwarsa dan kemudian dimusnahkan.

Kerjasama juga dapat dilakukan oleh Badan Pengawasan Obat Makanan dengan melakukan upaya preventif, untuk menanggulangi peredaran makanan kadaluwarsa dengan melakukan pembinaan dan pengawasan kepada para pedagang atau pelaku usaha. Pengawasan tersebut dilakukan dengan tahapan pre market yaitu pengawasan yang dilakukan sebelum produk tersebut diedarkan di masyarakat untuk di konsumsi dan pro market yaitu pengawasan yang di lakukan saat produk telah beredar atau dijajakan ke masyarakat.

Upaya represif yang di lakukan oleh pihak Badan Penyelesaian Sengketa Konsumen yaitu dengan melakukan mediasi, konsiliasi dan arbitrasi. Upaya-upaya tersebut dilakukan jika ada laporan atau pengaduan dari pihak konsumen. Berdasarkan hasil wawancara yang Penulis lakukan diperoleh info bahwa keterangan responden menyebutkan bahwa hampir keseluruhan toko/supermarket dan pedagang pernah menjual produk makanan.

${ }^{58}$ Philipus M. Hadjon, Perlindungan Hukum Bagi Rakyat Indonesia, Surabaya: PT. Bina Ilmu, 1987, Hal. 84

${ }^{59}$ Philipus M. Hadjon. Op.cit. Hal. 38 


\section{E. Kesimpulan}

Kesimpulan dari penelitian ini adalah sebagai berikut: Pertama, pelaksanaan Undang-Undang Nomor 8 Tahun 1999 tentang Perlindungan Konsumen terhadap produk makanan kadaluarsa di Kota Batam secara praktek pelaku usaha (pemilik toko) sudah memiliki rasa tanggung jawab mutlak (strick lialibility), di mana ketika konsumen konplein dalam hal barang kadaluwarsa mereka telah memberikan ganti rugi sesuai dengan kesepakatan. Terhadap barang yang kadaluwarsa pemilik toko melakukan tindakan mengembalikan barang kepada penjual, memusnahkan dan ada juga menjual barang dengan harga murah. Dari segi pengawasan dan pembinaan belum dilakukan sebagaimana diatur dalam Undang-Undang, sehingga pelaku usaha (penjual) banyak yang tidak terpantau berkenaan dengan produk makanan yang kadaluwarsa. Kedua, dampak Penerapan Undang-Undang Nomor 8 Tahun 1999 Tentang Perlindungan Konsumen Terhadap Produk Makanan Kadaluwarsa di Kota Batam adalah terjaminnya kepastian hukum bagi konsumen maupun bagi pelaku usaha. Hal ini terjadi karena adanya ketentuan hak dan kewajiban antara keduanya sehingga pelaku usaha harus lebih hati-hati untuk menyediakan atau menawarkan barang dagangan dengan maksud mengelabui atau membuat tindakan tidak senang. Ketika mereka lalai, maka sesuai dengan ketentuan perundang-undangan akan diminta pertanggungjawaban pelaku secara mutlak serta akan diminta pertanggungjawaban nya sehingga pihak konsumen yang dirugikan berhak untuk menuntut ganti rugi sesuai dengan besarnya kerugian yang diterima. Ketiga, solusi yang dapat dilakukan untuk mengatasi dampak negatif adalah dengan menerapkan teori efektivitas hukum oleh Soerjono Soekanto, yaitu dengan melakukan efektifitas hukum perlindungan konsumen baik dipengaruhi oleh faktor hukum itu sendiri, faktor penegak hukum, faktor masyarakat dan faktor budaya. Serta dengan mengukuhkan teori perlindungan hukum oleh Philiphus M. Hadjon melalui tindakan melakukan upaya preventif dan upaya represif. Upaya preventif adalah dengan melibatkan pihak Badan Penyelesaian Sengketa Konsumen dan pihak kepolisian dalam menanggulangi peredaran makanan kadaluwarsa yaitu melakukan pengawasan dan pembinaan kepada pelaku usaha dan konsumen, sidak atau razia ke Supermarket, Minimarket dan toko-toko perbelanjaan, serta melakukan penyitaan terhadap barangbarang yang ditemukan yang kemudian barang tersebut akan dimusnahkan, serta melakukan upaya hukum represif yang dilakukan oleh pihak Badan Penyelesaian Sengketa Konsumen yaitu dengan melakukan mediasi, konsiliasi dan arbitrasi. 


\section{DAFTAR PUSTAKA}

\section{Buku}

Ali, Zainuddin, 2006, Sosiologi Hukum, Sinar Grafika, Jakarta.

Azwar, Syaifuddin, 2012, Metode Penelitian, Pustaka Pelajar, Yogyakarta.

Barkatulah, Abdul Halim, 2008, Hukum Perlindungan Konsumen Kajian Teoretis dan Perkembangan Pemikiran, Nusa Media, Bandung.

Departemen Pendidikan Nasional, Kamus Besar Bahasa Indonesia Jakarta : Balai Pustaka, 2005.

Fuady, Munir, 2013, Teori-Teori Besar Dalam Hukum, Kencana, Jakarta.

HS, Salim, Erlies Septiana Nurbani, 2013, Penerapan Teori Hukum Pada Penelitian Penelitian dan Disertasi. Rajawali Pers, Jakarta.

Kristiyanti, Celina Tri Siwi, 2014, Hukum Perlindungan Konsumen, Sinar Grafika, Jakarta.

Madjon, Philips M, 1997, Tentang Wewenang, Yuridika, Nomor 5\&6 Tahun XII, Sep-Des.

Nasution, Az. 2011, Hukum Perlindungan Konsumen, Diadit Media. Jakarta.

Philipus M. Hadjon, 1987, Perlindungan Hukum Bagi Rakyat Indonesia, PT. Bina Ilmu, Surabaya.

Rajagukguk Dkk., Erman, 2000, Hukum Perlindungan Konsumen, Mandarmaju, Bandung.

Salim HS. Pengantar Hukum Perdata Tertulis BW. Cet VIII, Jakarta: Sinar Grafika, 2013.

Sasongko, Wahyu, 2007, Ketentuan-Ketentuan Pokok Hukum Perlindungan Konsumen Universitas Lampung., Bandar Lampung.

Shidarta, 2006, Hukum Perlindungan Konsumen Indonesia edisi Revisi 2006, Gramedia Widiasarana Indonesia, Jakarta.

Faktor-Faktor yang Mempengaruhi Penegeakan Hukum, Cetakan Kelima, Jakarta: Raja Grafindo Persada. 2004.

Siahaan, N. H. T.. 2005, Hukum Konsumen "Perlinungan Konsumen Dan Tanggung Jawab Produsen", Panta Rai., Jakarta.

Sidabalok, Janus, 2010, Hukum Perlindungan Konsumen Di Indonesia, PT Citra Aditya Bakti, Bandung.

Soekanto, Soerjono, 2008, Pengantar Penelitian Hukum, UI-Press, Jakarta. 1996, Pengantar Penelitian Hukum, Rajawali Pers, Jakarta.

Suratman, dan Dillah, Philips, 2014, Metode Penelitian Hukum, Alfabeta, Bandung. Zainal dan Asikin, Amiruddin, 2004, Pengantar Metode Penelitian Hukum, Raja Grafindo Persada, Jakarta. 


\section{Artikel}

Supranto dan Nandan, 2012, Petunjuk Praktis Penelitian Ilmiah Untuk Menyusun Skripsi, Penelitian, dan Disertasi, Mitra Wacana Media, Jakarta.

Departemen Pendidikan Nasional, 2005, Kamus Besar Bahasa Indonesia, Balai Pustaka, Jakarta.

\section{Website}

Polewali Mandar, 2014, "Status Hukum”, Serial Blog, URL: http://statushukum. com/ tentang-status-hukum Diakses 29 Juli 2016

Artikel yang berjudul "Kejahatan Konsumen" di akses pada www. elisaturatmi. wordpress. com pada tanggal 2 Agustus 2016 pada pukul 10. 00

\section{Peraturan Perundang-undangan}

Undang-Undang Republik Indonesia Nomor 8 Tahun 1999 Tentang Perlindungan Konsumen.

Undang-Undang Nomor 18 Tahun 2012 tentang Pangan

Undang-Undang Republik Indonesia Nomor 3 Tahun 2014 Tentang Perindustrian. 